\title{
SOIL-CORROSION STUDIES, 1932. RATES OF LOSS OF WEIGHT ANDPITTING OF FERROUS AND NON-FERROUS SPECIMENS AND METALLIC PROTECTIVE COATINGS
}

\author{
By K. H. Logan and R. H. Taylor
}

ABSTRACT

In 1922 the Bureau of Standards began the study of the action of soils on buried pipe. Reports on this investigation have been issued at intervals of approximately 2 years. The first report described the soils and materials under investigation, and the 1930 reports summarized all data then available. This report deals only with data on specimens removed in 1932. Consideration of these data does not materially alter the conclusions reached earlier that the character of the soil controls the rates of corrosion of ferrous materials and that in the same soil all of the commonly used ferrous materials corrode at nearly the same rate.

For the soils investigated, the rate of corrosion in a soil of a given series as identified by the United States Department of Agriculture appears to be characteristic of the series and it seems probable that the rate of corrosion in any location in a soil belonging to a known soil series can be predicted when the corrosiveness at one location in that series has been determined, provided the location of the pipe with respect to the soil horizons of the series is taken into account.

Metallic protective coatings show signs of failure, after 8 years in several of the more corrosive soils. Several non-ferrous metals and alloys are more resistant to soil action than the ferrous materials commonly used.

\section{CONTENTS}

I. Introduction

II. Ferrous materials removed in 1932

1. Pipe line materials buried in 1922

(a) Rates of loss of weight

(b) Rates of penetration by pitting

2. Special cast pipe and fittings

(a) Corrosion of high-silicon cast iron

(b) Pipe materials buried in 1924

III. Estimation of pipe life in terms of experimental data

1. Effect of duration of exposure.

2. Effect of methods of determining rates of corrosion

3. Effect of length and diameter of pipe. 129

4. Variations in pipe life under apparently similar conditions - $\quad 130$

5. Estimation of rates of corrosion of pipe lines from Bureau data

IV. Corrosion at different locations in the same soil series.

V. Corrosion of non-ferrous metals...

1. Cast brass and attached nipples

2. Copper and copper alloy pipes and rods

3. Lead cable sheath.

4. Parkway cable

134

135

136

5. Miscellaneous metals and alloys 
VI. Corrosion of metallic protective coatings . . . .

1. Galvanized pipe and sheet. 139

2. Relation of weight of zinc to corrosion

3. Lead coated pipe... 142

4. Calorized pipe 143

5. Sheradized and lead-coated bolts

VII. Conclusion

VIII. Acknowledgments... 144

Appendix 1. Errata in earlier reports. 145

\section{INTRODUCTION}

In 1922 the Bureau of Standards buried 6 sets of specimens of the more commonly used pipe materials in 47 soils for the purpose of studying the effects of soils on buried pipe systems. Later, the original specimens were supplemented by others buried for special purposes. The original plans for these tests called for the removal of sets of specimens at 2-year intervals, but data secured from some of of the test locations indicated that, on account of the low corrosivity of the soils, a less frequent examination of specimens in some locations would be sufficient. In 1932, therefore, specimens were removed only from the more corrosive soils and from such other locations as special conditions called for. The data therefore are not indicative of the average corrosiveness of all soils. If the present plans for the corrosion work are carried out, the last of the original specimens will be removed from the corrosive soils in 1934 and a complete report on the original undertaking will be prepared as soon thereafter as circumstances permit.

The form of the present paper and the method of treating the data are similar to those adopted in previous reports. Since only the 1932 data are here tabulated, the reader must refer to the earlier reports for other information regarding the investigation. In Technologic Paper no. $368^{1}$ the nature of the investigation, the soils, and materials are described, and in Research Papers nos. $329^{2}$ and $359^{3}$ the data obtained up to the end of 1930 are summarized.

A study of these papers is quite essential to a correct interpretation of the data since the results of any experiment depend largely on the conditions under which it is conducted. Some of the relations of the data presented in this and earlier reports to the corrosion of pipe lines are discussed briefly in section III of this report.

\section{FERROUS MATERIALS REMOVED IN 1932}

\section{PIPE LINE MATERIALS BURIED IN 1922}

\section{(a) RATES OF LOSS OF WEIGHT}

Specimens of the commonly used pipe materials which had been exposed to the more corrosive soils for 10 years were removed from 21 locations. To the data on these specimens have been added the values for specimens buried about 2 years later in another corrosive soil. Table 1 gives the significance of the identification letters for the various materials. The table also contains information on other

\footnotetext{
1 Logan, K. H., Ewing, S. P., and Yeomans, C. D., Bureau of Standards soil-corrosion studies: I. Soils, materials, and results of early observations, B.S.Tech. Papers, vol. 22 (T368, 50k), p. 447, 1928.

○ Logan, K. H., and Grodsky, V. A., Soil-corrosion studies, 1930: Rates of corrosion and pitting of bare ferrous specimens, B.S.Jour. Research, vol. 7 (RP329, 10 6 ), p. 1, July 1931.

${ }^{3}$ Logan, K. H., Soil-corrosion studies: Non-ferrous metals and alloys, metallic coatings and specially prepared ferrous pipes removed in 1930, B.S.Jour. Reseasch, vol. 7 (RP359, 10k), p. 585, September 1931.
} 
materials to be discussed later. In most cases two specimens of each material were removed at each location. Since the specimens differ in diameter and in the duration of exposure it has been necessary, in order to compare different materials and different soils, to reduce the data to rates of loss of weight and penetration by pitting.

TABLE 1.-Identification of materials

11/2-INCH PIPE SPECIMENS

\begin{tabular}{c|c}
\hline Identification letters & \multicolumn{1}{c}{ Material } \\
\hline a. & $\begin{array}{c}\text { Tables 2 and 3: } \\
\text { Pure open-hearth iron, lap-welded. } \\
\text { Hand-puddled wrought iron, butt-welded. } \\
\text { Bessemer steel, butt-welded. } \\
\text { Scale-free Bessemer steel, butt-welded. }\end{array}$ \\
\hline
\end{tabular}

3-INCH PIPE SPECIMENS, LAP-WELDED

\begin{tabular}{l|l}
\hline $\mathrm{A}$ & $\begin{array}{l}\text { Tables 2, 3, 6, 7: } \\
\text { Pure open-hearth iron. } \\
\text { Hand-puddled wrought iron. } \\
\text { Open-hearth steel. } \\
\mathrm{K}\end{array}$ \\
$\mathrm{M}$ & $\begin{array}{l}\text { Bessemer steel. } \\
\text { Bessemer steel, scale-free, butt-welded. } \\
\text { Open-hearth steel, 0.2 percent copper. }\end{array}$ \\
\hline
\end{tabular}

6-INCH CAST-IRON PIPE SPECIMENS

\begin{tabular}{|c|c|}
\hline 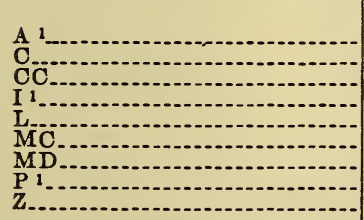 & $\begin{array}{l}\text { Tables } 2,3,5,6,7 \text { : } \\
\text { Southern cast iron. } \\
\text { deLavaud centrifugal process. } \\
\text { deLavaud centrifugal process, only outside exposed to soil. } \\
\text { Monocast centrifugal process. } \\
\text { Pit cast in sand molds, northern ore. } \\
\text { Pit cast iron, machined surfaces (4 in.). } \\
\text { deLavaud cast iron, machined surfaces. } \\
\text { Pit cast iron, southern ore. } \\
\text { Pit cast in sand molds, southern ore (rough surfaces). }\end{array}$ \\
\hline
\end{tabular}

\section{MISCELLANEOUS FERROUS CASTINGS}

\begin{tabular}{l|l}
\hline & $\begin{array}{r}\text { Tables } 4 \text { and } 5: \\
2 \text {-in. cast steel elbow. } \\
2 \text {-in. malleable iron elbow. } \\
21 / 2 \text {-in. O.D. high-tensile cast-iron nipple. } \\
\text { 3-in. high-silicon cast iron. }\end{array}$ \\
\hline
\end{tabular}

COPPER AND COPPER ALLOY PIPES AND RODS

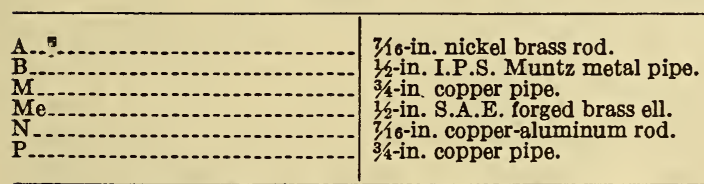

1 Specimens buried in 1928 for special tests. 
TABLE 1.-Identification of materials-Continued

CHARAOTER AND DIMENSIONS OF MISCELLANEOUS SPECIMENS

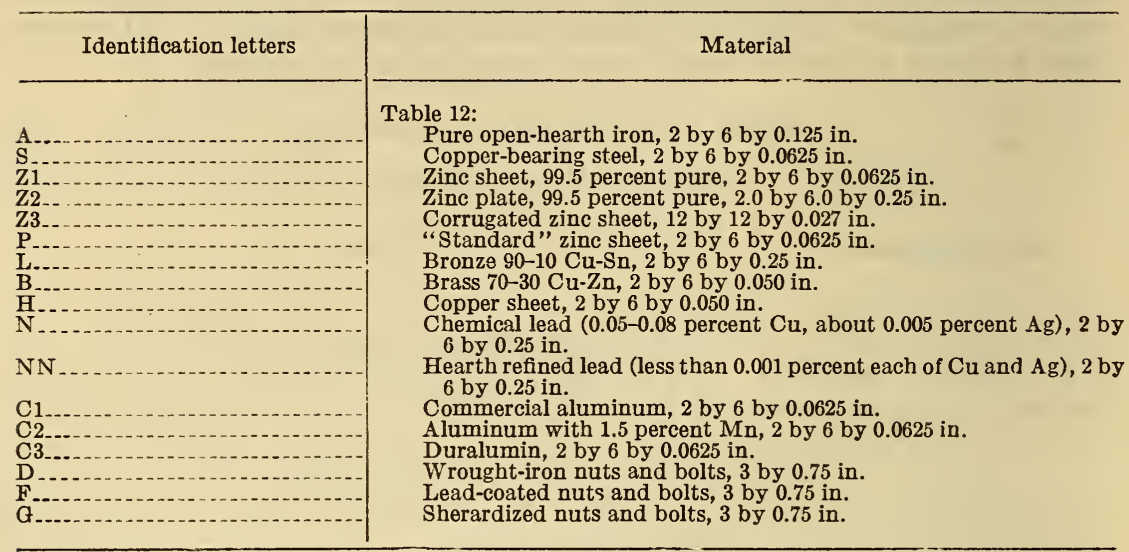

GALVANIZED MATERIALS AND WEIGHTS OF COATINGS PER SQUARE FOOT

\begin{tabular}{|c|c|}
\hline $\begin{array}{l}\mathrm{D} \\
\mathrm{X}\end{array}$ & 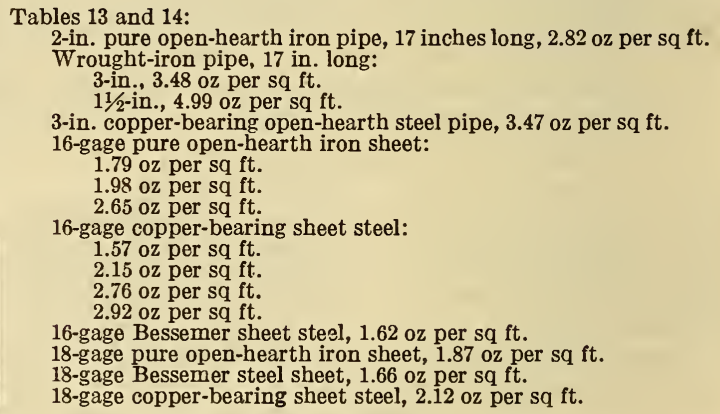 \\
\hline
\end{tabular}

To express the rates of loss of weight in table 2, which is comparable with tables 11, 13, 15, and 17 of Research Paper 329, for the rolled and deLavaud materials, the losses of two specimens of the same size from the same location have been averaged. Only one specimen of northern and southern cast iron was removed from each soil. In some locations " $C$ " specimens were not buried until 1924. The data for these specimens are given in table 5 . The average for all the specimens from the same soil is given in the right-hand column. This average is the arithmetical average of all the data on loss of weight given in the same line, and does not take account of the differences in areas of specimens. Although it might be considered more logical to weight the data in accordance with the areas exposed this would give undue weight to the data for certain materials which are represented only by large-size specimens. For example, the total area of the deLavaud specimens in some soils is four times that of the pure open-hearth iron specimens and twice that of the other cast-iron specimens.

Although specimens were not removed in 1932 from the least corrosive soils under investigation, it will be observed from the table that the lowest recorded rate of loss of weight is less than one tenth 
of the highest rate. It will be noticed also that except for the 6-inch cast-iron specimens, the rates of loss of weight of the different materials in any one soil are usually of the same order of magnitude. This is best illustrated by the averages at the bottom of the page. The spread of the data which can be attributed to errors and lack of control of conditions is roughly indicated by the differences in rates of loss of 11/2- and 3-inch specimens of the same material such as specimens $b$ and $B$, which were from the same rolling mill. Specimens $\mathrm{e}$ and $\mathrm{M}$ are both Bessemer steel and should behave similarly. It will be found that, on the average, the differences in loss of weight of specimens of the same material are of the same order as the differences between materials, so far as the rolled materials are concerned. The cast specimens seem to be significantly different from the rolled specimens in a number of soils. This difference between types of materials is more marked with respect to penetration, as will be seen in the section on rates of pitting.

TABLE 2.-Average rates of loss of weight of 10-year-old specimens of ferrous pipe

[In ounces per square foot per year]

\begin{tabular}{|c|c|c|c|c|c|c|c|c|c|c|c|c|c|c|}
\hline \multirow{2}{*}{$\begin{array}{l}\text { Soil } \\
\text { no. }\end{array}$} & \multirow{2}{*}{ oil } & \multirow{2}{*}{ 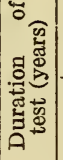 } & \multicolumn{4}{|c|}{$\begin{array}{l}\text { 11/2-inch wrought } \\
\text { specimens } 1\end{array}$} & \multicolumn{4}{|c|}{$\begin{array}{l}\text { 3-inch wrought } \\
\text { specimens }\end{array}$} & \multicolumn{3}{|c|}{$\begin{array}{c}\text { 6-inch cast-iron } \\
\text { specimens }\end{array}$} & \multirow{2}{*}{ 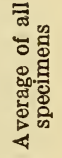 } \\
\hline & & & a & b & $\theta$ & y & B & K & M & $\mathrm{Y}$ & C1 & $\mathrm{L}^{2}$ & $Z^{2}$ & \\
\hline $\begin{array}{r}1 \\
3 \\
8 \\
11 \\
14\end{array}$ & $\begin{array}{l}\text { Allis silt loam } \\
\text { Cecil clay loam } \\
\text { Fargo clay loam } \\
\text { Hagerstown loam } \\
\text { Hempstead silt loam. }\end{array}$ & $\begin{array}{r}9.60 \\
10.14 \\
9.86 \\
10.02 \\
9.88\end{array}$ & $\begin{array}{r}0.840 \\
.419 \\
.521 \\
.136 \\
.383\end{array}$ & $\begin{array}{r}0.976 \\
.456 \\
.522 \\
.168 \\
.649\end{array}$ & \begin{tabular}{|}
1.014 \\
.426 \\
.464 \\
.202 \\
.457
\end{tabular} & $\begin{array}{r}0.917 \\
.405 \\
.462 \\
.196 \\
.536\end{array}$ & $\begin{array}{r}0.976 \\
.313 \\
.525 \\
.167 \\
.502\end{array}$ & $\begin{array}{l}1.053 \\
.356 \\
.535 \\
.181 \\
.404\end{array}$ & $\begin{array}{r}0.932 \\
.375 \\
.571 \\
.165 \\
.463\end{array}$ & $\begin{array}{r}0.945 \\
.392 \\
.574 \\
.146 \\
.367\end{array}$ & $\begin{array}{c}1.058 \\
(3) \\
.852 \\
.123 \\
.335\end{array}$ & $\begin{array}{l}1.005 \\
.641 \\
1.064 \\
.111 \\
.577\end{array}$ & $\begin{array}{r}1.126 \\
.419 \\
.969 \\
.181 \\
.601\end{array}$ & $\begin{array}{r}0.986 \\
4.420 \\
.642 \\
.161 \\
.479\end{array}$ \\
\hline $\begin{array}{l}16 \\
18 \\
19 \\
20 \\
22\end{array}$ & $\begin{array}{l}\text { Knox } \\
\text { Lindl } \\
\text { Maho } \\
\text { Mem }\end{array}$ & $\begin{array}{r}10.02 \\
9.79 \\
9.71 \\
9.60 \\
9.65\end{array}$ & $\begin{array}{l}.670 \\
.285 \\
.314 \\
.409 \\
.699\end{array}$ & $\begin{array}{l}.663 \\
.360 \\
.331 \\
.505 \\
.720\end{array}$ & $\begin{array}{l}.678 \\
.327 \\
.333 \\
.476 \\
.781\end{array}$ & $\begin{array}{l}.617 \\
.339 \\
.298 \\
.427 \\
.661\end{array}$ & $\begin{array}{l}.574 \\
.303 \\
.318 \\
.536 \\
.744\end{array}$ & $\begin{array}{l}.624 \\
.351 \\
.297 \\
.477 \\
.710\end{array}$ & $\begin{array}{l}.686 \\
.318 \\
.319 \\
.496 \\
.780\end{array}$ & $\begin{array}{l}.619 \\
.299 \\
.305 \\
.436 \\
.675\end{array}$ & $\begin{array}{l}(3) \\
.359 \\
.266 \\
.549 \\
.698\end{array}$ & $\begin{array}{l}.849 \\
.493 \\
.306 \\
.690 \\
.825\end{array}$ & $\begin{array}{l}.824 \\
.475 \\
.514 \\
.493 \\
.812\end{array}$ & $\begin{array}{l}4.680 \\
.355 \\
.327 \\
.499 \\
.737\end{array}$ \\
\hline $\begin{array}{l}23 \\
28 \\
29 \\
32 \\
33\end{array}$ & $\begin{array}{l}\text { Merced silt loam } \\
\text { Montezuma clay ado } \\
\text { Muck } \\
\text { Ontario loam } \\
\text { Peat... }\end{array}$ & $\begin{array}{r}10.18 \\
7.73 \\
10.05 \\
9.57 \\
9.66\end{array}$ & $\begin{array}{r}1.920 \\
1.507 \\
1.604 \\
.218 \\
1.151\end{array}$ & $\begin{array}{l}2.125 \\
1.650 \\
1.336 \\
.338 \\
1.288\end{array}$ & $\begin{array}{l}1.897 \\
1.873 \\
1.377 \\
.321 \\
1.186\end{array}$ & $\begin{array}{l}1.860 \\
1.948 \\
1.390 \\
.258 \\
1.015\end{array}$ & $\begin{array}{l}1.936 \\
1.983 \\
1.485 \\
.318 \\
1.046\end{array}$ & $\begin{array}{l}1.940 \\
2.121 \\
1.525 \\
.248 \\
1.029\end{array}$ & $\begin{array}{l}2.130 \\
1.707 \\
1.472 \\
.295 \\
1.182\end{array}$ & $\begin{array}{r}2.136 \\
2.364 \\
1.549 \\
.274 \\
1.087\end{array}$ & $\begin{array}{c}2.912 \\
(3) \\
(3) \\
.345 \\
1.342\end{array}$ & $\begin{array}{l}2.778 \\
2.809 \\
1.513 \\
.359 \\
1.478\end{array}$ & \begin{tabular}{r|}
6.116 \\
\hdashline 1.727 \\
.491 \\
1.253
\end{tabular} & $\begin{array}{r}2.523 \\
41.996 \\
1.498 \\
.315 \\
1.187\end{array}$ \\
\hline $\begin{array}{l}34 \\
37 \\
39 \\
40 \\
42\end{array}$ & $\begin{array}{l}\text { Penn silt loam. } \\
\text { St. Johns fine sand.- } \\
\text { Sassafras silt loam..- } \\
\text { Sharkey clay.- } \\
\text { Susquehanna clay.- }\end{array}$ & $\begin{array}{r}9.89 \\
10.06 \\
9.89 \\
10.04 \\
10.07\end{array}$ & $\begin{array}{r}.420 \\
.900 \\
.462 \\
.689 \\
1.145\end{array}$ & $\begin{array}{r}.484 \\
.857 \\
.524 \\
.722 \\
1.058\end{array}$ & $\begin{array}{r}.467 \\
.800 \\
.497 \\
.727 \\
1.202\end{array}$ & $\begin{array}{r}.416 \\
.767 \\
.455 \\
.598 \\
1.245\end{array}$ & $\begin{array}{l}.458 \\
.820 \\
.534 \\
.811 \\
.879\end{array}$ & \begin{tabular}{r|}
.397 \\
.862 \\
.504 \\
.719 \\
1.105
\end{tabular} & $\begin{array}{l}.433 \\
.848 \\
.476 \\
.923 \\
.925\end{array}$ & $\begin{array}{l}.449 \\
.954 \\
.485 \\
.748 \\
.913\end{array}$ & $\begin{array}{c}.555 \\
(3) \\
.578 \\
(3) \\
(3)\end{array}$ & $\begin{array}{l}.606 \\
.917 \\
.689 \\
1.031 \\
1.119\end{array}$ & $\begin{array}{r}.642 \\
.827 \\
.735 \\
.903 \\
2.169\end{array}$ & $\begin{array}{r}.484 \\
4.855 \\
.540 \\
4.787 \\
41.176\end{array}$ \\
\hline $\begin{array}{l}43 \\
45 \\
46\end{array}$ & $\begin{array}{l}\text { Tidal marsh } \\
\text { Unidentified alkali soil... } \\
\text { Unidentified sandy loam }\end{array}$ & $\begin{array}{r}9.91 \\
9.85 \\
10.15\end{array}$ & $\begin{array}{r}1.166 \\
1.395 \\
.397\end{array}$ & $\begin{array}{r}1.153 \\
1.210 \\
.461\end{array}$ & $\begin{array}{r}1.063 \\
1.210 \\
.477\end{array}$ & $\begin{array}{r}1.717 \\
1.226 \\
.404\end{array}$ & $\begin{array}{r}1.048 \\
1.268 \\
.429\end{array}$ & $\begin{array}{r}1.134 \\
1.326 \\
.353\end{array}$ & $\begin{array}{r}.989 \\
1.250 \\
.421\end{array}$ & $\begin{array}{l}1.210 \\
1.374 \\
.387\end{array}$ & $\begin{array}{r}1.305 \\
1.536 \\
.440\end{array}$ & $\begin{array}{l}1.152 \\
1.770 \\
.392\end{array}$ & $\begin{array}{c}.950 \\
-.797 \\
\end{array}$ & $\begin{array}{r}1.172 \\
1.357 \\
.507\end{array}$ \\
\hline & & & & 807 &. & .7 & .781 & & 89 & & & & 1.096 & \\
\hline
\end{tabular}

1 A verage of 2 specimens in each soil.

1 specimen only in each soil.

3 Specimens buried late-see table 5 .

4 These averages do not represent all materials or locations.

From the standpoint of service, the rate of loss of weight is not of great importance so far as underground corrosion is concerned, since a pipe which is punctured by corrosion may show less loss of weight than one generally corroded but still serviceable. 
TABLE 3.-Weighted average rates of maximum pitting of 10-year-old ferrous pipe specimens

(In mils per year)

\begin{tabular}{|c|c|c|c|c|c|c|c|c|c|c|c|c|c|c|}
\hline \multirow{2}{*}{$\begin{array}{l}\text { Soil } \\
\text { no. }\end{array}$} & \multirow{2}{*}{ Soil } & \multirow{2}{*}{ 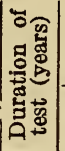 } & \multicolumn{4}{|c|}{$\begin{array}{l}\text { 11/2-in. wrought } \\
\text { specimens } 1\end{array}$} & \multicolumn{4}{|c|}{$\begin{array}{l}\text { 3-in. Wrought } \\
\text { specimens? }\end{array}$} & \multicolumn{3}{|c|}{$\begin{array}{l}\text { 6-in. cast-iron } \\
\text { specimens }\end{array}$} & \multirow{2}{*}{ 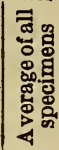 } \\
\hline & & & a & b & e & y & B & $\mathbf{K}$ & $\mathbf{M}$ & $\mathbf{Y}$ & $\mathrm{Ca}$ & $L^{4}$ & $z^{4}$ & \\
\hline $\begin{array}{r}1 \\
3 \\
8 \\
11 \\
14\end{array}$ & $\begin{array}{l}\text { Allis silt loam } \\
\text { Cecil clay loam } \\
\text { Fargo clay loam... } \\
\text { Hagerstown loam } \\
\text { Hempstead silt loam }\end{array}$ & $\begin{array}{r}9.60 \\
10.14 \\
9.86 \\
10.02 \\
9.88\end{array}$ & $\begin{array}{r}6.7 \\
11.7 \\
7.6 \\
7.5 \\
12.1\end{array}$ & $\begin{array}{r}7.6 \\
6.9 \\
6.6 \\
6.0 \\
10.7\end{array}$ & $\begin{array}{r}8.9 \\
7.1 \\
6.2 \\
7.5 \\
13.2\end{array}$ & $\begin{array}{r}9.5 \\
7.4 \\
5.8 \\
7.0 \\
13.2\end{array}$ & $\begin{array}{l}9.4 \\
7.2 \\
6.1 \\
8.3 \\
9.7\end{array}$ & $\begin{array}{l}8.8 \\
6.0 \\
8.7 \\
6.4 \\
9.1\end{array}$ & $\begin{array}{r}8.9 \\
7.8 \\
6.9 \\
6.5 \\
11.2\end{array}$ & $\begin{array}{r}8.2 \\
7.7 \\
7.5 \\
6.7 \\
13.5\end{array}$ & \begin{tabular}{r|}
9.5 \\
$(5)$ \\
11.9 \\
3.5 \\
5.5
\end{tabular} & $\begin{array}{r}19.1 \\
15.9 \\
19.0 \\
3.3 \\
5.5\end{array}$ & $\begin{array}{r}20.8 \\
12.8 \\
13.7 \\
7.1 \\
5.7\end{array}$ & $\begin{array}{l}10.67 \\
9.05 \\
9.09 \\
6.35 \\
9.97\end{array}$ \\
\hline $\begin{array}{l}16 \\
18 \\
19 \\
20 \\
22\end{array}$ & $\begin{array}{l}\text { Kalmia fine sandy l } \\
\text { Knox silt loam..... } \\
\text { Lindley silt loam... } \\
\text { Mahoning silt loam } \\
\text { Memphis silt loam. }\end{array}$ & $\begin{array}{r}10.02 \\
9.79 \\
9.71 \\
9.60 \\
9.65\end{array}$ & $\begin{array}{l}6.9 \\
4.7 \\
6.4 \\
3.3 \\
5.2\end{array}$ & $\begin{array}{l}6.1 \\
4.7 \\
5.3 \\
5.4 \\
6.4\end{array}$ & $\begin{array}{l}6.4 \\
5.2 \\
6.3 \\
4.0 \\
5.6\end{array}$ & $\begin{array}{l}5.5 \\
5.9 \\
5.6 \\
3.3 \\
5.9\end{array}$ & $\begin{array}{l}6.7 \\
4.9 \\
5.6 \\
4.2 \\
6.8\end{array}$ & $\begin{array}{l}6.4 \\
6.4 \\
6.7 \\
3.7 \\
6.5\end{array}$ & $\begin{array}{l}6.4 \\
5.0 \\
6.6 \\
4.1 \\
6.3\end{array}$ & $\begin{array}{l}6.6 \\
4.5 \\
7.1 \\
3.5 \\
6.5\end{array}$ & $\begin{array}{l}(8) \\
6.2 \\
5.9 \\
7.7 \\
8.6\end{array}$ & $\begin{array}{l}15.3 \\
11.2 \\
10.7 \\
10.8 \\
12.1\end{array}$ & $\begin{array}{r}13.5 \\
12.9 \\
15.0 \\
7.3 \\
15.7\end{array}$ & $\begin{array}{l}5.21 \\
7.78\end{array}$ \\
\hline $\begin{array}{l}23 \\
28 \\
29 \\
32 \\
33\end{array}$ & $\begin{array}{l}\text { Merced silt loam } \\
\text { Montezuma clay adob } \\
\text { Muck. } \\
\text { Ontario loam } \\
\text { Peat... }\end{array}$ & $\mid \begin{array}{r}10.18 \\
7.73 \\
10.05 \\
9.57 \\
9.66\end{array}$ & $\begin{array}{r}14.6 \\
17.7 \\
16.2 \\
4.5 \\
11.9\end{array}$ & $\begin{array}{r}17.8 \\
16.0 \\
9.7 \\
5.7 \\
8.6\end{array}$ & \begin{tabular}{|r|}
14.5 \\
15.5 \\
7.3 \\
4.8 \\
9.5
\end{tabular} & $\begin{array}{r}15.3 \\
12.4 \\
9.2 \\
4.6 \\
7.7\end{array}$ & $\begin{array}{r}13.1 \\
16.4 \\
7.9 \\
5.1 \\
10.7\end{array}$ & $\begin{array}{r}14.7 \\
20.0 \\
11.0 \\
5.0 \\
10.1\end{array}$ & $\begin{array}{r}13.1 \\
14.5 \\
8.8 \\
5.4 \\
10.6\end{array}$ & \begin{tabular}{r|}
15.2 \\
18.9 \\
15.3 \\
8.6 \\
11.0
\end{tabular} & $\begin{array}{c}16.9 \\
(5) \\
(5) \\
6.4 \\
11.1\end{array}$ & $\begin{array}{r}20.7 \\
15.7 \\
13.0 \\
5.4 \\
15.0\end{array}$ & $\begin{array}{r}31.5 \\
14.7 \\
6.8 \\
17.7\end{array}$ & $\begin{array}{r}17.04 \\
16.34 \\
11.31 \\
5.66 \\
11.26\end{array}$ \\
\hline $\begin{array}{l}34 \\
37 \\
39 \\
40 \\
42\end{array}$ & $\begin{array}{l}\text { Penn silt loam. } \\
\text { St. Johns fine sa } \\
\text { Sassafras silt loa } \\
\text { Sharkey clay.-- } \\
\text { Susquehanna cle }\end{array}$ & $\mid \begin{array}{r}9.89 \\
10.06 \\
9.89 \\
10.04 \\
10.07\end{array}$ & $\begin{array}{l}8.2 \\
6.9 \\
6.9 \\
7.5 \\
8.3\end{array}$ & $\begin{array}{l}4.8 \\
7.1 \\
4.3 \\
6.2 \\
8.4\end{array}$ & $\begin{array}{r}8.4 \\
8.9 \\
4.3 \\
8.7 \\
10.3\end{array}$ & $\begin{array}{l}9.6 \\
7.3 \\
5.2 \\
6.2 \\
9.2\end{array}$ & $\begin{array}{l}6.6 \\
7.3 \\
5.0 \\
5.9 \\
9.3\end{array}$ & $\mid \begin{array}{r}6.9 \\
6.8 \\
6.6 \\
6.8 \\
12.1\end{array}$ & $\begin{array}{l}7.3 \\
8.0 \\
5.3 \\
5.9 \\
9.8\end{array}$ & $\begin{array}{r}10.2 \\
10.8 \\
8.1 \\
7.5 \\
9.9\end{array}$ & $\begin{array}{c}8.2 \\
(8) \\
7.5 \\
(8) \\
(8)\end{array}$ & $\begin{array}{r}8.3 \\
5.8 \\
8.0 \\
7.0 \\
13.3\end{array}$ & $\begin{array}{r}8.6 \\
9.1 \\
6.9 \\
8.8 \\
18.7\end{array}$ & $\begin{array}{r}7.92 \\
7.80 \\
6.19 \\
7.03 \\
10.93\end{array}$ \\
\hline \multirow[t]{2}{*}{$\begin{array}{l}43 \\
45 \\
46\end{array}$} & $\begin{array}{l}\text { Tidal marsh } \\
\text { Unidentified alkali so } \\
\text { Unidentifled sandy lo }\end{array}$ & $\begin{array}{r}9.91 \\
9.85 \\
10.15\end{array}$ & $\begin{array}{r}11.4 \\
14.6 \\
7.3\end{array}$ & $\begin{array}{r}7.7 \\
11.5 \\
9.3\end{array}$ & $\begin{array}{r}7.1 \\
14.0 \\
6.7\end{array}$ & $\begin{array}{r}7.4 \\
11.9 \\
8.2\end{array}$ & $\begin{array}{r}13.0 \\
11.3 \\
7.6\end{array}$ & $\begin{array}{r}9.5 \\
13.7 \\
6.0\end{array}$ & $\begin{array}{r}10.3 \\
12.8 \\
7.8\end{array}$ & $\begin{array}{r}13.7 \\
15.2 \\
7.4\end{array}$ & $\begin{array}{r}15.7 \\
13.5 \\
4.2\end{array}$ & $\begin{array}{r}7.2 \\
19.9 \\
3.6\end{array}$ & 9.1 & $\begin{array}{r}10.19 \\
13.84 \\
6.91\end{array}$ \\
\hline & & & 9. & 7.95 & 8.28 & 7.97 & 8.18 & 8.60 & 8. & 9.72 & & 56 & 12. & \\
\hline
\end{tabular}

1 A verage of the deepest pit on each of 2 specimens.

2 Average of the 2 deepest pits on each of 2 specimens.

3 Average of the 4 deepest pits on 1 specimen.

$\checkmark$ Specimens buried late. See table 5 .

\section{(b) RATES OF PENETRATION BY PITTING}

Table 3 shows the rates of penetration of the 10-year-old specimens. It is comparable with tables $12,14,16$, and 18 of Research Paper 329. For $1 \frac{1}{2}$-inch specimens the values for rates of pitting are derived from the average of the single deepest pit on each of 2 specimens. For the 3-inch specimens the average of the 2 deepest pits on each of 2 specimens was taken. For the 6 -inch specimens, 4 pits were averaged on each specimen, but there were removed from each soil only 1 " $L$ " and 1 " $Z$ " specimen. An examination of table 3 will make it clear that no one rolled material is outstanding in its resistance to all soils. Previous reports show that for any one period certain materials have lower rates of penetration in certain soils, but it is difficult to determine whether this apparent superiority is real. For example, in table 3 , in soil no. 1 , specimen "a" shows a rate of pitting lower than any other material in the same soil. This material showed next to the lowest rate of pitting in the same soil for the 8-year period. For the two preceding periods, however, its rates of pitting in the same soil were higher than the average rate found for the rolled materials. It is doubtful, therefore, that the performance of this material is significantly different from that of other materials in the soil. It seems more probable that the character of the test makes it impossible to detect small differences in the behavior of different materials. In certain cases, however, the differences are of sufficient magnitude 
to be significant. It is probable that any large differences in the behavior of different materials would be clearly evident from the data. It should be remembered, however, that there are no great differences in the composition of the rolled materials under consideration. The economic importance of such differences in materials as are now apparent or may appear when additional data have been obtained depends on the conditions under which the material is to be used. For example, if the cost of the pipe in an installation is but a small fraction of the cost of the complete structure, as when a gas or water service is laid under a city pavement, a small increase in the life of the material may justify a very considerable expenditure, especially if the rate of corrosion is high.

There is little doubt that underground corrosion is an electrochemical process and that strains, impurities, and segregation cause potential differences which influence the rate of corrosion, but it must be remembered that when commercial materials are used as received from the rolling mill (except for the removal of grease, shop coating, and dirt) there is a relatively large potential difference between the oxidized surface and the unoxidized metal for any material and that other potential differences are inevitably set up on account of unequalities in the supply of oxygen as the soil shrinks and swells with changes in moisture content. The data indicate that soil conditions control the rate of corrosion of buried ferrous metals. Soil conductivity, soil acidity, moisture, and oxygen supply have been suggested as factors influencing corrosion. Whether these are the elementary factors or the results of more fundamental causes is not definitely known. An attempt to correlate the corrosion data with the physical and chemical characteristics of the soils is in progress.

\section{SPECIAL CAST PIPE AND FITTINGS}

(a) CORROSION OF HIGH-SILICON CAST IRON

In addition to specimens of the more commonly used pipe materials, specimens of high-silicon cast iron were also buried. This material is used primarily in connection with the manufacture and use of corrosive chemicals and would not be chosen for the transportation of oil, water, or gas under normal conditions because of its cost and the difficulties in making connections with it. As will be seen from table 4 , the rates of loss of weight are relatively very low in all soils. In 1932 as well as on previous occasions, there were a very few specimens showing 1 or 2 deep pits. These pits have been attributed to flaws or the corrosion of segregated areas rather than to the action of soils on the normal metal. At variance with this explanation, however, is the fact that the worst pitting occurred in the same soil both in 1930 and in 1932, and on each occasion both specimens were affected. In another soil a deep pit occurred on 1 specimen in 1930 and on 1 in 1932 . 
TABLE 4.-Average rates of loss of weight of high-silicon cast iron specimens

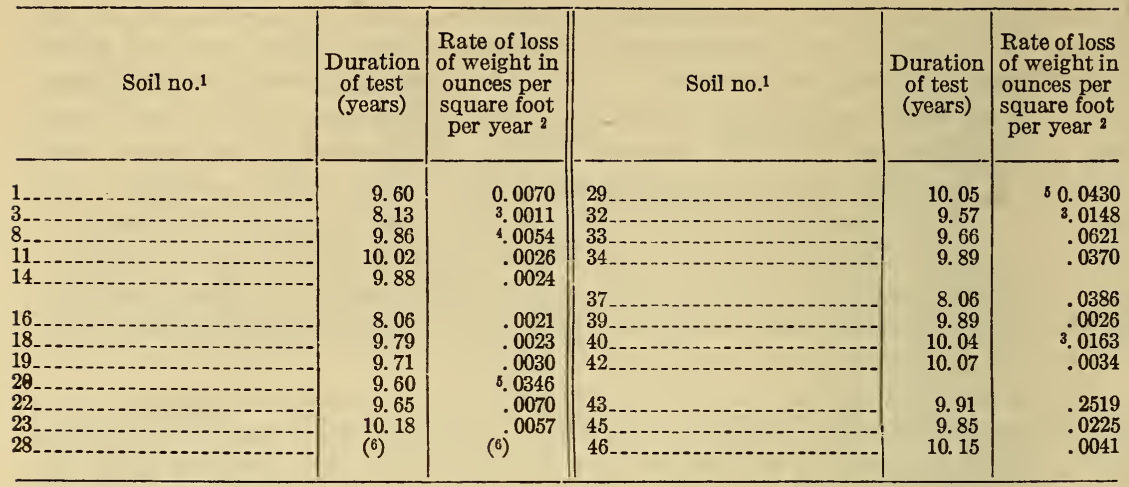

1 For names of soils see table 2 .

2 Average of 2 specimens except as noted.

31 specimen only. Companion specimen chipped or broken.

41 specimen only.

3 Softened at one or more points.

${ }^{6}$ Both specimens chipped and corroded.

\section{(b) PIPE MATERIALS BURIED IN 1924}

Two years after the first test was started, it was decided to bury a group of cast materials sponsored by the American Foundrymen's Association. Since attention had been called to the fact that the inside surface of deLavaud cast iron differed somewhat from the outside surface it was decided to bury additional samples of this material with the outside surface only exposed to soil. To determine the effect of the surface layers on the two kinds of cast iron, specimens of deLavaud and pit cast iron with machined surfaces were provided for six soils. The results of the 1932 examination of these specimens are given in table 5 . The data on the pit cast specimens $\mathrm{P}$ may be used as a guide for correlating this table with the tables previously given.

The data are inadequate for determining the relative merits of the materials, but the following indications may be noted. Removing the original surface from the deLavaud specimens apparently did not affect the rate of pitting. On the average, the machined pit castiron specimens MC behaved similarly to the unmachined pit cast specimens $\mathrm{P}$, but the pits on the machined specimens were deeper in 4 out of 5 soils. The high-tensile cast iron (V) appears to behave similarly to ordinary cast iron (P).

The cast steel specimens and the malleable iron specimens were in the form of elbows and on account of the double curvature of their surfaces, it was impossible to determine pit depth on these materials with the apparatus at hand. The rates of loss of weight of these materials are about the same as those of the pit cast-iron specimens and visual inspection shows no marked differences in rates of pitting when the elbows are compared with other materials in the same soil. While there are apparent differences in the rates of corrosion of the cast-steel and malleable-iron specimens, in some soils one appears better, and in other soils the other appears better. It is doubtful whether the differences shown in the table are significant. 
TABLE 5.-Corrosion of special cast iron pipes and fittings

(A) RATES OF LOSS OF WEIGHT OF SPECIAL CAST SPECIMENS

[In ounces per square foot per year]

\begin{tabular}{|c|c|c|c|c|c|c|c|c|c|c|}
\hline \multirow{2}{*}{$\begin{array}{l}\text { Soil } \\
\text { no. }\end{array}$} & \multirow{2}{*}{ Soil } & \multirow{2}{*}{$\begin{array}{l}\text { Dura- } \\
\text { tion of } \\
\text { test } \\
\text { (years) }\end{array}$} & \multicolumn{8}{|c|}{ Specimens ${ }^{1}$} \\
\hline & & & $\mathbf{P}$ & $\mathrm{CC}$ & $I^{2}$ & $M D$ & $\mathrm{MC}$ & $\mathrm{v}$ & $\mathrm{E}$ & 8 \\
\hline \multirow{3}{*}{\begin{tabular}{r|r}
3 & \\
13 & \\
16 & \\
28 & \\
29 &
\end{tabular}} & \multirow{3}{*}{ 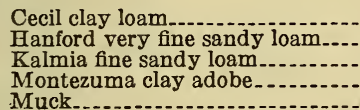 } & \multirow{3}{*}{$\begin{array}{l}8.13 \\
8.25 \\
8.06 \\
7.73 \\
8.10\end{array}$} & & \multirow{3}{*}{$\begin{array}{l}0.366 \\
1.399 \\
1.431 \\
1.628 \\
2.09\end{array}$} & & & & & & \multirow[b]{2}{*}{0.889} \\
\hline & & & 0.949 & & $\cdots$ & 1.139 & 1.780 & 1.278 & 1.260 & \\
\hline & & & $\begin{array}{l}3.020 \\
1.510\end{array}$ & & & 1.31 & 1.34 & 1.31 & $\begin{array}{l}2.530 \\
1.200\end{array}$ & $\begin{array}{l}2.404 \\
1.140\end{array}$ \\
\hline 37 & St. & 8. 06 & & 1. 134 & & & & & & \\
\hline 40 & & 8.09 & & 9. 54 & & & & & & $\cdots$ \\
\hline${ }_{43}^{42}$ & $\begin{array}{l}\text { Susquehar } \\
\text { Tidal mar }\end{array}$ & 8.08 & .419 & 2.004 & 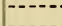 & .091 & $\cdot 019$ & .096 & .006 & .725 \\
\hline 45 & Unidentified alkali soil_: & 8.70 & 2.075 & 2. 510 & & 2.374 & 1.945 & 2. 020 & 1.847 & 1. 575 \\
\hline
\end{tabular}

(B) WEIGHTED MaXimum Rate of PITTing

[In mils per year]

\begin{tabular}{|c|c|c|c|c|c|c|c|c|c|c|}
\hline 3 & Cecil clay loam.-. & 8.13 & & 7.4 & & & & & & \\
\hline 13 & Hanford very fine sandy loam... & 8.25 & 20.2 & 15.7 & 16. 8 & 12.0 & ${ }^{4} 30.3$ & 23.1 & ${ }^{5} \mathrm{Sa}$ & $\mathrm{Sa}$ \\
\hline 16 & Kalmia fine sandy loam & 8. 06 & 416 & 13.1 & 3338 & & & & $P$ & $\mathrm{~Pa}$ \\
\hline 29 & $\begin{array}{l}\text { Montezuma clay a } \\
\text { Muck. }\end{array}$ & 8.10 & $\begin{array}{l}41.0 \\
11.7\end{array}$ & 39.7 & 6.4 & 9.2 & 13. 7 & 12.6 & $\mathrm{~Pa}$ & $\mathrm{~Pa}$ \\
\hline 37 & St. Johns fine sand & 8. 06 & & 5. 1 & & & & & & \\
\hline 40 & Sharkey clay.-- & 8. 09 & 136 & 8. 52 & 110 & 9.5 & 177 & 133 & $\mathrm{Sa}$ & ph \\
\hline 43 & Tidal marsh clay. & $\begin{array}{l}\text { 8.08 } \\
\text { 8. } 63\end{array}$ & $\begin{array}{l}13.6 \\
25.3\end{array}$ & 9. 2 & $\begin{array}{ll}11.0 \\
228\end{array}$ & 9. 0 & 142 & 15.3 & $\mathrm{Sh}$ & $\mathrm{Pb}$ \\
\hline 45 & Unidentified alkali soil-- & 8.70 & 15. 6 & 12. 2 & 7.3 & 422.6 & 425.4 & 20.1 & $\mathrm{~Pa}$ & $\mathrm{Sa}$ \\
\hline
\end{tabular}

1 See table 1 for names of materials.

3 Specimens partly coated with cement.

3 One specimen only.

4 Punctured.

o C, no pitting; S, slight pitting; $P$, general pitting; a, specimens about the same as others in the same soil; $b$, specimens better than others in the same soil; $w$, specimens worse than others in the same soil.

\section{ESTIMATION OF PIPE LIFE IN TERMS OF EXPERI- MENTAL DATA}

Since the principal use to which the data in this and similar reports will be put is the estimation of the life of pipe underground, it is important to call attention to the fact that the data here presented are, strictly speaking, directly applicable only to specimens of similar sizes exposed for equal periods to similar soil conditions. In order to make practical applications of the data it is necessary to take into account the differences in the conditions of exposure of the specimens reported on and the pipe line under consideration.

\section{EFFECT OF DURATION OF EXPOSURE}

It has been shown in previous reports that the rate of corrosion decreases with the time of exposure in most soils. This is shown in figures 1 to 4 in which the average total depths of the deepest pits on the rolled specimens have been plotted for each period for the soils from which specimens were removed in 1932. The pit depths have been weighted as explained in the discussion of table 3 . The curves serve three purposes. (1) They show the spread of the data and hence indicate their reproducibility. The significance of this will be dis- 
cussed a little later. (2) They show that the corrosiveness of soils differs widely. (3) They show that for most soils the curves bend downward, which indicates that usually the rate of penetration decreases as the period of exposure increases. From this it follows that the life of a pipeline cannot be estimated from data for a single period of exposure such as those in table 3 . It is necessary to know also

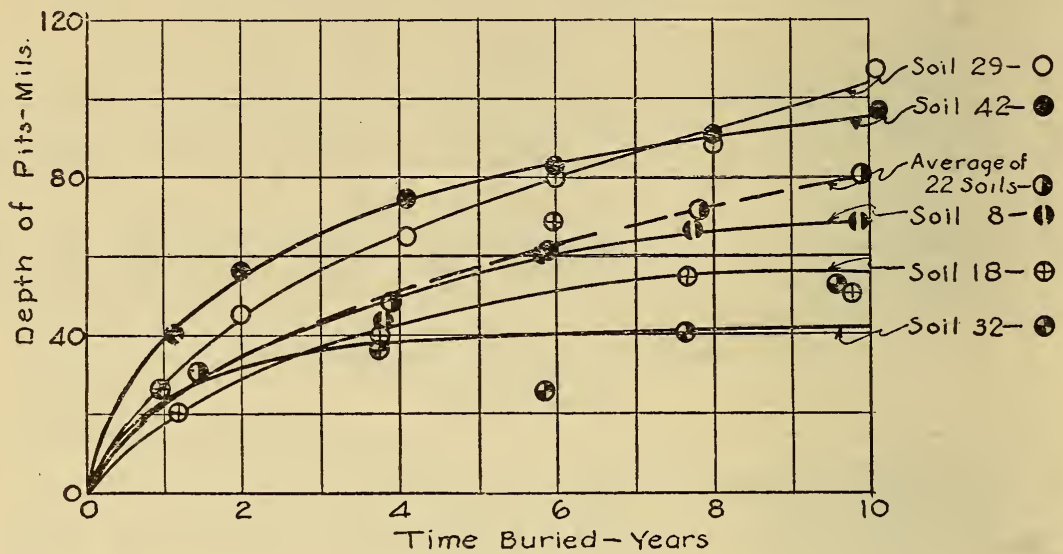

FIGURE 1.

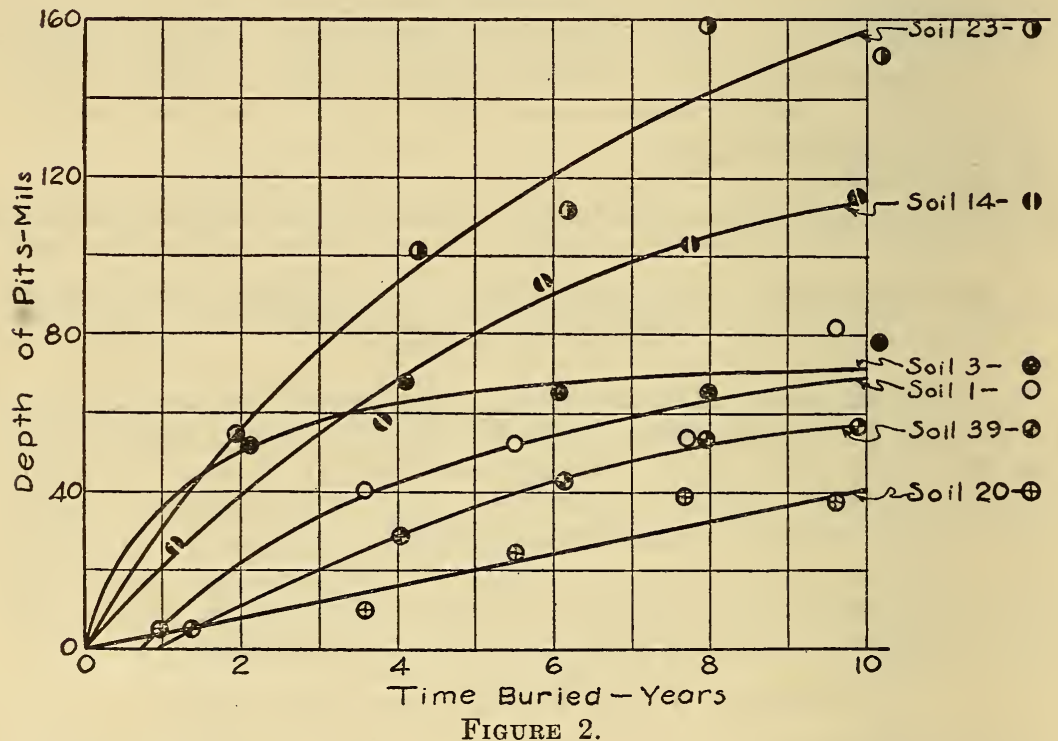

the effect of time on the rate of corrosion. The change in rate of penetration is not the same for all soils.

\section{EFFECT OF THE METHODS OF DETERMINING RATES OF CORROSION}

The value of the rate of corrosion will, of course, depend upon the way in which it is determined. The data given in table 3 as weighted maximum rates of penetration are actually the averages of the depths of from 2 to 8 pits on 2 specimens 6 inches long and from 1/1/2 to 6 inches 
in diameter. The data used for plotting the curves in figures 1 to 4 are the averages of the depths of 24 pits on a total area of about 5 square feet of pipe surface. Obviously, if the single deepest pit on say a 30 -foot length of 10 -inch pipe had been taken as the basis for expressing the rate of penetration, a considerably larger value would have been found under the same soil condition.

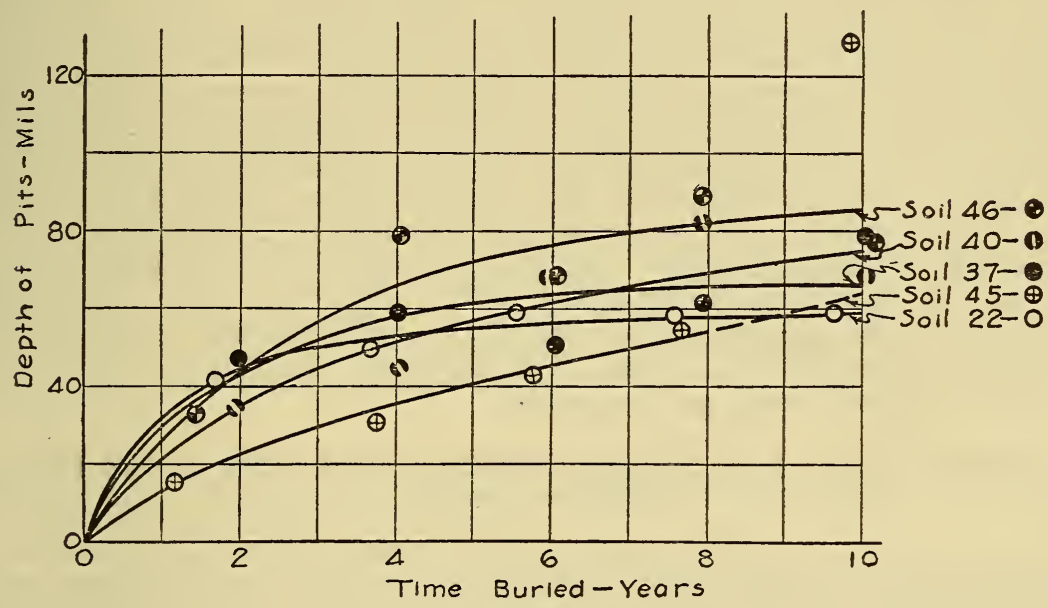

Figdre 3.

\section{EFFECT OF LENGTH AND DIAMETER OF PIPE}

In addition to the fact that the maximum depth of pit will probably increase with the area exposed, there are other reasons for expecting that the maximum depth of pit on a pipe line will be somewhat greater

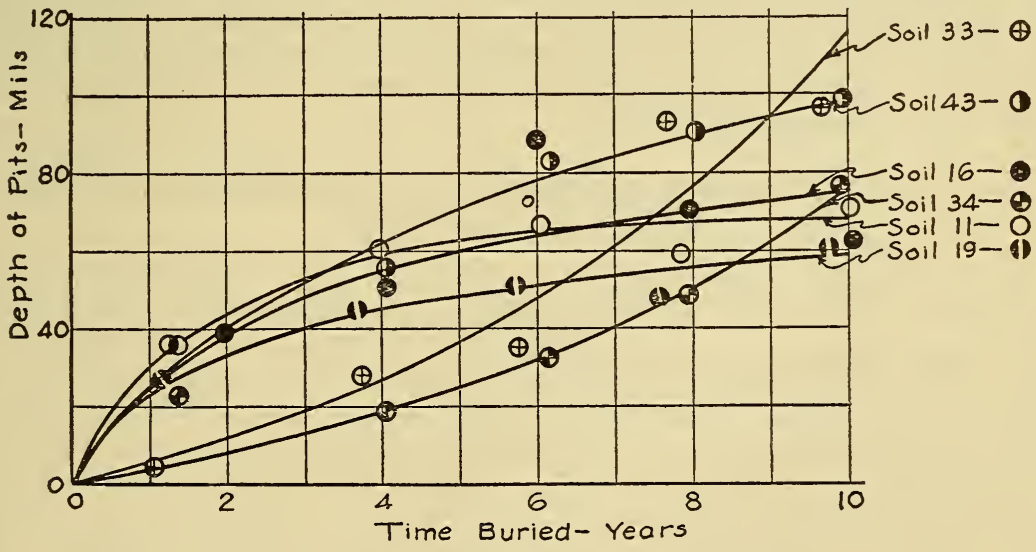

FIGURE 4.

than is indicated by the specimens in this report for the same soil conditions. The top and bottom of a pipe of large diameter will probably be exposed to different conditions with respect to both soil and moisture, and these differences will result in galvanic potentials and increased corrosion. Galvanic potentials will likewise be created because the pipe line will pass through different soils. The pipe may also be connected to metals which are cathodic to it. 


\section{VARIATIONS IN PIPE LIFE UNDER APPARENTLY SIMILAR CONDITIONS}

A comparison of the data for different specimens of the same material, such as those for wrought-iron or Bessemer steel, in the same soil and with the same period of exposure indicates quite clearly that there are rather wide limits within which the results are not reproducible. The important feature of this observation is not the spread of the values but the fact that under practical field conditions the rate of pitting of a material is not an exact or reproducible quantity. It follows that two lengths of the same kind of pipe in the same soil will not last exactly the same time and that two lengths of different kinds of pipe in the same soil may last different times, not because of the superiority of one of the materials but because of accidental and undeterminable circumstances. Citations of isolated instances of longer life of one material as compared with another are not necessarily evidence of the superiority of one of the materials and do not give assurance that the same relation between the materials will be observed wherever they are compared.

\section{ESTIMATION OF RATES OF CORROSION OF PIPE LINES FROM BUREAU DATA}

From the foregoing discussion it will be seen that the Bureau data should not be taken as the exact rates at which working lines will corrode but only as indications of the relative corrosion-resisting properties of the materials tested and the relative corrosiveness of the soils investigated. It is not possible to reduce the experimental data to rates of corrosion of operating lines by the application of a reduction factor because the conditions under which each pipe line is laid are different. On the average, the maximum rate of corrosion of a pipe line will be greater than that given in this report, but in a given location the single maximum pit depth may be less because of accidental conditions. Nevertheless the corrosion data collected may be accepted as a record of what has happened and as at least a suggestion as to what may happen again.

\section{CORROSION AT DIFFERENT LOCATIONS IN THE SAME SOIL SERIES}

The investigation originally involved 47 soils, all of which were different. It is, therefore, impossible to determine from the original test data whether the corrosion observed at a test site is a characteristic of the soil series ${ }^{4}$ involved or merely of the locality chosen for the test. To throw more light on the question several widely different soil types were chosen in 1928 and specimens of pipe were buried at several locations in each of these types. To determine at the same time the relation of soil texture to corrosion, several locations were chosen in the same soil series but where the textures differed. In addition, locations were chosen in which the character of the salts was the same but the amount of the salts differed. Unfortunately, in order to secure different amounts of salts in any one soil series, it was necessary to choose locations differing in texture or drainage and the effect of differences in the amounts of salts may be obscured by the other differences mentioned.

1 Soils alike in all particulars except texture are said to belong to the same series. If they are alike in texture also they belong to the same type. 
In attempting to determine whether the rate of corrosion throughout the areas mapped as a single soil type or series is the same or in trying to predict the rate of corrosion at one point in a given soil series from the known rate of corrosion at some other point in the same series, several things must be kept in mind: The rate of corrosion usually decreases with time and this must be considered in comparing corroded pipes of different ages. The texture of the soil as indicated in the names assigned by the Department of Agriculture refers to the uppermost or "A" horizon. The textures of the A, B, and C soil horizons usually are not the same and the acidity of the several horizons may increase or decrease with their distance from the surface. Consequently the corrosiveness of the different horizons of a soil series may differ. Although within limits each horizon is uniform in its nature throughout a soil type, the thickness of the horizons and their distances from the surface vary because of local conditions. Two pipes may lie in different horizons and therefore may be subject to somewhat different soil conditions either because they have not been laid at the same depths or because at a given depth the horizons are different.

The specimens in any one soil series reported on in tables 6 and 7 were placed at the same depth. In different soil series the depths varied between 2 and 5 feet.

Since consideration of the data of tables 6 and 7 leads to the same general conclusions, the discussion of them will be confined mostly to table 7 . This table is in agreement with table 3 in its indication that in a given soil the rates of penetration of the different rolled materials are similar.

To determine whether or not the data show significant differences between the individual soils of a series, the best available criterion is the consistency of the apparent differences with respect to the several materials under observation. Using the Cecil series for illustration because the maximum amount of data is available for this series, one sees that with the exception of soil no. 105 the differences between materials in the same location are of the same order of magnitude as the differences between specimens of the same materials in different types of the series. The data for the other soil series also indicate that corrosion throughout any one series is approximately the same. This, of course, is to be expected if the actual classification of the soils at each location conforms to the definition of soil type and series, provided that the corrosion is controlled by the character of the soil.

Tables 6 and 7 indicate that soil characteristics govern the corrosion of ferrous pipes in soils. It is possible, therefore, that the classification of soils which the Department of Agriculture has made for a large part of the United States can be used to obtain an approximate value for their corrosiveness throughout a given soil series if the rate of corrosion at one location in the series has been determined. The Bureau of Standards is obtaining such data for approximately 50 soil series. The Department of Agriculture has defined about 1,500 different series. Since the rate of corrosion is affected by local soil conditions and by factors independent of the soil, only approximate values for rates of corrosion can be hoped for and it is probable that, since this is all that is expected, many soil series can be grouped together as being similar with respect to corrosivity 
provided that the relationship between corrosion and the chemical and physical properties of soils can be determined. An investigation is now under way to see whether or not this can be done.

\section{TABLE 6.-Relation of soil series to rates of loss of weight of ferrous specimens}

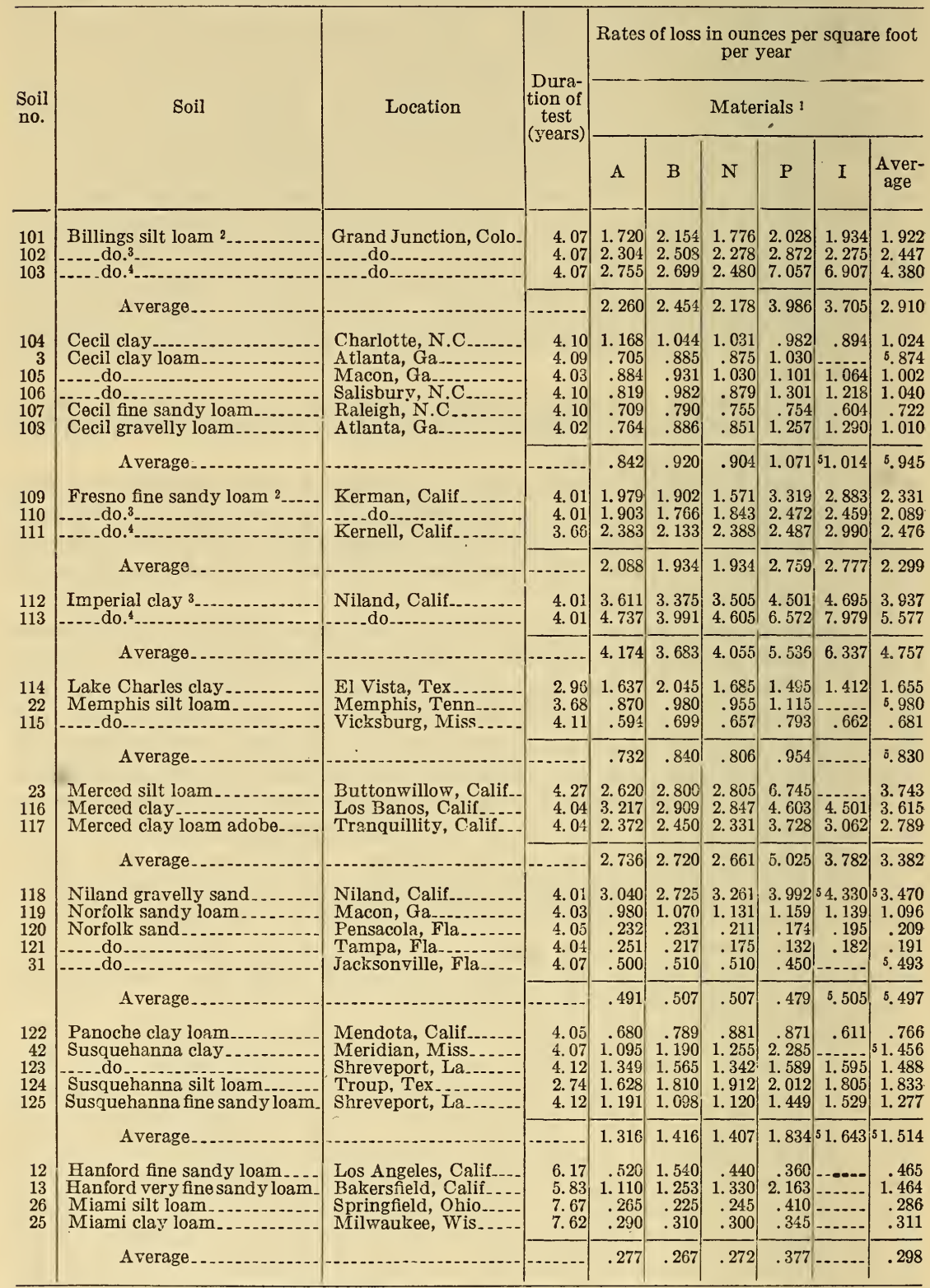

1 Seo table 1 for identification of materials.

${ }^{2}$ Low alkali.

3 Moderate alkali.

4 High alkali.

5 These averages do not represent all materials. 
TABLE 7.-Relation of soil series to weighted rates of maximum pitting of ferrous specimens

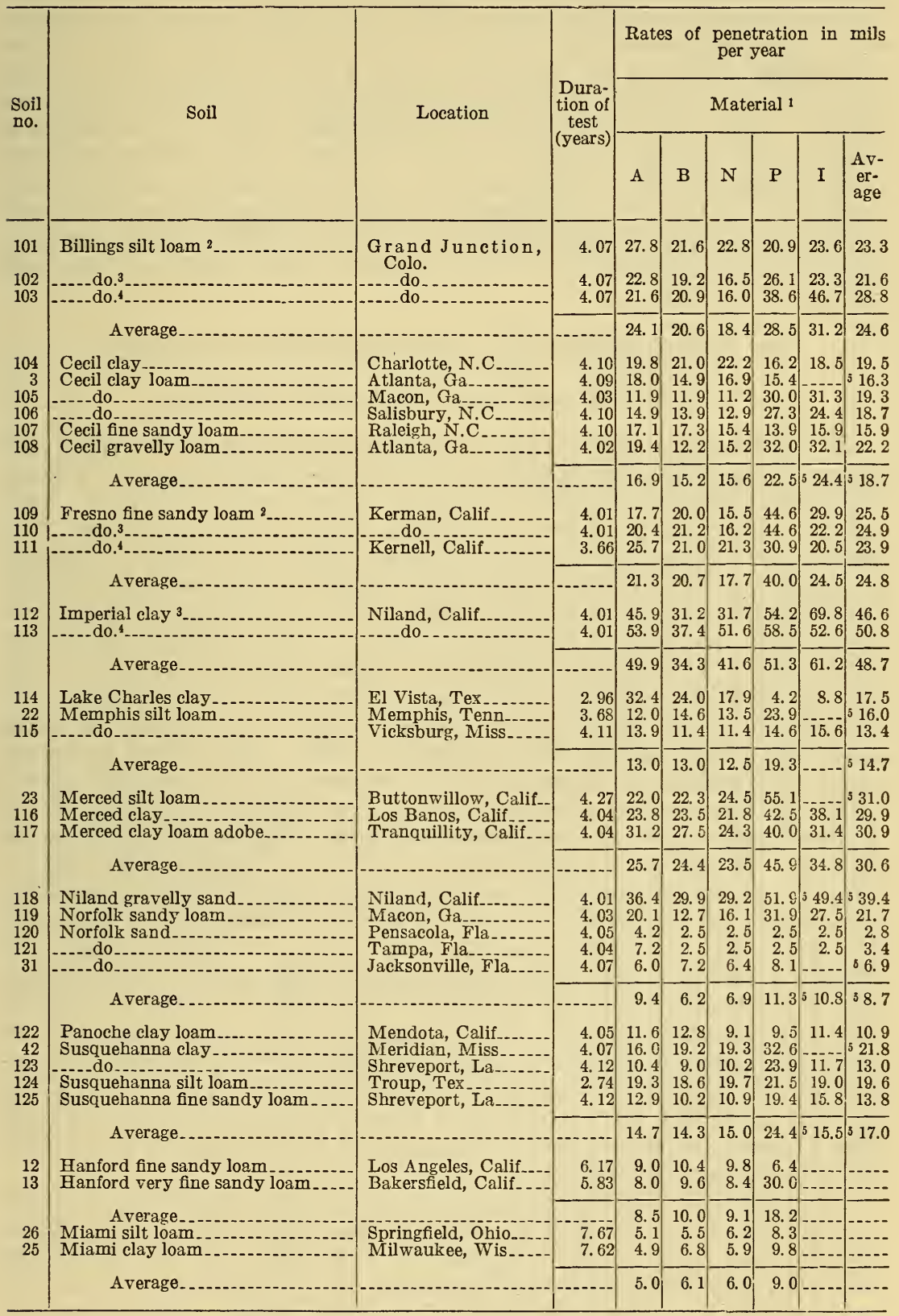

1 See table 1 for identification of materials.

2 Low alkali.

3 Moderate alkali.

4 High alkali.

5 These averages do not represent all materials. 
Sometimes the rules for the designation of a soil series do not take account of all factors affecting the soil. This is the case with respect to the amount of soluble salts which a soil may contain and under some circumstances with respect to the amount and distribution of rainfall. This is illustrated in table 6 by the differences in the rate of loss of weight of specimens in the two soils of the Hanford series. The more corrosive soil at Bakersfield, soil no. 13, contains a considerable amount of soluble salts. In view of the difference in the corrosiveness of the two soils in the Hanford series it is evident that in using data from one location to estimate the corrosiveness of a soil of the same series at another location, it is necessary to make sure that there is no difference in soil characteristics and that only one soil horizon is involved.

\section{CORROSION OF NON-FERROUS METALS}

\section{CAST BRASS AND ATTACHED NIPPLES}

One of the ways suggested for avoiding the losses arising from corrosion when ferrous materials are used is the substitution of a more corrosion-resistant material. Copper alloys and lead have been employed for this purpose to a limited extent for a long time. The early use of brass was for cocks, valves, and valve parts. In many instances cast brass was connected to other metals and it is possible that the differences of potential arising from the combination may have resulted in accelerated corrosion of one of the materials involved. To study this problem, specimens of four cast-copper alloys were connected to short lengths of brass, galvanized iron, and lead pipe and buried in all of the 47 test sites in 1924 . Specimens of these materials were removed from 22 soils in 1932 . Since there appeared to be no significant difference in the behavior of the copper alloys, although they varied considerably in composition, the losses of the 12 castings in each soil have been averaged. The results are given in table 8. It will be seen that the rate of loss of weight of the caps is very low in all soils except the tidal marsh (soil 43), where it is of the same order of magnitude as that for ferrous materials in moderately corrosive soils. In two soils the rate of loss of weight of the lead nipples attached to the brass caps was very high and in several other soils it approached the rate for ferrous materials. A large proportion of the lead nipples showed about the same rate of corrosion as that of unattached strips of lead in the same soils, as will be seen by comparing the data with those for the $\mathrm{H}$ specimens in table 10 . In a few locations the rate of corrosion was considerably greater or less than that of the unattached lead specimens, but it seems proballe that the differences were accidental.

The corroded brass nipples, which are of Muntz metal, were inadequately cleaned. It was discovered this year that there existed between the bright surface heretofore assumed to be the unaffected material, and the actual unaffected part of the specimen, a dark-red spongy substance which was rather soft and brittle. This substance was found to exist in almost every specimen, regardless of the corrosiveness of the soil from which the specimen was taken. It ranged in amount from a very thin layer to almost the entire thickness of the specimen according to the corrosiveness of the soil. For this reason losses of weight reported in table 8 on these nipples are in 
most cases much too small. Since Muntz metal unconnected with anything else has shown much the same deterioration in some soils it is doubtful that much of the corrosion of the nipples can be attributed to galvanic action between the nipples and the cast caps.

TABLE 8.-Rates of loss of weight of cast-brass caps and of lead, brass, and galvanized nipples attached to the caps

\begin{tabular}{|c|c|c|c|c|c|}
\hline \multirow[b]{2}{*}{ Soil number 1} & \multirow[b]{2}{*}{$\begin{array}{c}\text { Duration } \\
\text { of test } \\
\text { (years) }\end{array}$} & \multicolumn{4}{|c|}{ Loss in ounces per square foot per year } \\
\hline & & $\begin{array}{l}\text { Avg. of } \\
12 \text { brass } \\
\text { caps }\end{array}$ & $\begin{array}{l}\text { Avg. of } 4 \\
\text { lead nip- } \\
\text { ples }\end{array}$ & $\begin{array}{c}\text { Avg. of } 4 \\
\text { brass nip- } \\
\text { ples }\end{array}$ & $\begin{array}{c}\text { Avg. of } 4 \\
\text { galvan- } \\
\text { ized steel } \\
\text { nipples }\end{array}$ \\
\hline $\begin{array}{l}1 \ldots . . \\
3 \ldots \\
8 \ldots \\
11 . . \\
13 . .\end{array}$ & $\begin{array}{l}8.62 \\
8.13 \\
8.73 \\
8.66 \\
8.25\end{array}$ & $\begin{array}{l}0.007 \\
.010 \\
.008 \\
.014 \\
.007\end{array}$ & $\begin{array}{r}2.770 \\
5.495 \\
2.101 \\
1.412 \\
.208\end{array}$ & $\begin{array}{l}(3) \\
0.051 \\
.136 \\
.057 \\
4.122\end{array}$ & $\begin{array}{r}12.200 \\
.322 \\
.503 \\
.298 \\
2.806\end{array}$ \\
\hline $\begin{array}{l}14 \\
16 \\
18 \\
19 \\
19 \\
20\end{array}$ & $\begin{array}{l}8.76 \\
8.06 \\
8.60 \\
8.59 \\
8.62\end{array}$ & $\begin{array}{l}.003 \\
.007 \\
.004 \\
.009 \\
.008\end{array}$ & $\begin{array}{l}.459 \\
2.142 \\
.195 \\
4.402 \\
.594\end{array}$ & $\begin{array}{l}.034 \\
.0341 \\
.032 \\
.076 \\
.133\end{array}$ & $\begin{array}{r}.213 \\
.500 \\
.275 \\
.266 \\
. .331\end{array}$ \\
\hline $\begin{array}{l}23 \ldots \ldots \\
28, \ldots \\
32 \\
33 \\
32\end{array}$ & $\begin{array}{l}8.25 \\
7.73 \\
8.10 \\
8.63 \\
8.63\end{array}$ & $\begin{array}{r}8.040 \\
8.008 \\
.022 \\
.008 \\
.038\end{array}$ & $\begin{array}{l}8.168 \\
2.163 \\
2.123 \\
4.223\end{array}$ & $\begin{array}{l}(3) \\
-(3) \\
4.057 \\
.393\end{array}$ & \begin{tabular}{l}
$(7)$ \\
\hdashline 1.514 \\
1.122 \\
4.547
\end{tabular} \\
\hline $\begin{array}{l}37 \ldots \ldots \ldots \\
39 \ldots \ldots \ldots \\
40 \ldots \ldots . . \\
42 \ldots \ldots\end{array}$ & $\begin{array}{l}8.06 \\
8.51 \\
8.09 \\
8.08\end{array}$ & $\begin{array}{r}.033 \\
.043 \\
.001 \\
.009\end{array}$ & $\begin{array}{l}4.626 \\
4.462 \\
.512 \\
4.518\end{array}$ & $\begin{array}{l}.202 \\
.277 \\
.131 \\
.061\end{array}$ & $\begin{array}{r}1.065 \\
\left.{ }^{(10)}\right)^{506} \\
.321\end{array}$ \\
\hline $\begin{array}{l}43 \ldots \ldots \\
45 \ldots \ldots \\
46 \ldots\end{array}$ & $\begin{array}{l}8.63 \\
8.70 \\
8.69\end{array}$ & $\begin{array}{l}.392 \\
.012 \\
.007\end{array}$ & $\begin{array}{r}4.038 \\
.064 \\
.362\end{array}$ & $\begin{array}{r}.004 \\
4.158 \\
.034\end{array}$ & $\begin{array}{r}.673 \\
23.764 \\
.577\end{array}$ \\
\hline
\end{tabular}

1 See table 2 for names of soils.

2 Average of only 2 specimens.

3 Some specimens not weighed because of stripped threads.

4 A verage of only 3 specimens.

3 Only 1 specimen weighed.

0.2 sets of specimens removed.

7 Specimens completely corroded away.

3 A verage of only 4 specimens.

- Average of 8 specimens.

10 Specimens missing.

Note.-In soils $8,23,29,33$, and 39 the brass caps connected to the lead nipples experienced considerably more corrosion than caps attached to brass or iron nipples.

The losses of the galvanized nipples were severe in several soils. As the nipples were threaded at each end after being galvanized and as part of the threads were exposed, some of the corrosion loss is a loss of iron, rather than of zinc. However, in a few soils, much, if not all, of the zinc disappeared and in one location the nipples were so deteriorated that they broke when picked up. Since both iron and zinc corrode badly in this soil, the corrosion is not necessarily to be attributed to the attachment of the nipple to the brass cup.

\section{COPPER AND COPPER-ALLOY PIPES AND RODS}

Two years after the cast caps, referred to above, were buried, it was decided to test specimens of copper and brass pipe since, at that time, these materials were being advocated as substitutes for lead in water-service connections in city streets. It was not planned to inspect these specimens in 1932, but local conditions made it advisable 
to remove sets of these specimens from three sites. The data obtained from these specimens are given in table 9. The depth of the pits was insufficient to justify measurement because of the low accuracy of the results obtainable.

\section{TABLE 9.-Corrosion of copper and copper-alloy pipes and rods}

[Losses in ounces per square foot per year]

\begin{tabular}{|c|c|c|c|c|c|c|}
\hline \multirow{2}{*}{ Materials ${ }^{2}$} & \multicolumn{2}{|c|}{$\begin{array}{l}\text { Soil no. } 11^{1} \\
6.08 \text { years }\end{array}$} & \multicolumn{2}{|c|}{$\begin{array}{l}\text { Soil no. } 22 \\
5.97 \text { years }\end{array}$} & \multicolumn{2}{|c|}{$\begin{array}{l}\text { Soil no. } 34 \\
5.86 \text { years }\end{array}$} \\
\hline & Loss & $\begin{array}{c}\text { Condi- } \\
\text { tion }\end{array}$ & Loss & $\begin{array}{l}\text { Condi- } \\
\text { tion }\end{array}$ & Loss & $\begin{array}{c}\text { Condi- } \\
\text { tion }\end{array}$ \\
\hline $\begin{array}{l}\mathrm{A} \\
\mathrm{N} \\
\mathrm{M} \\
\mathrm{P} \\
\mathrm{M}\end{array}$ & $\begin{array}{l}0.094 \\
.024 \\
.026 \\
.011 \\
.067 \\
.062\end{array}$ & $\begin{array}{c}\mathrm{Pd}^{3} \\
\mathrm{~d} \\
\mathrm{P} \\
\mathrm{P} \\
\mathrm{Pd}\end{array}$ & $\begin{array}{l}0.286 \\
.067 \\
.079 \\
.085 \\
.208 \\
.177\end{array}$ & $\begin{array}{l}\mathrm{Pd} \\
\mathrm{d} \\
\mathrm{P} \\
\mathrm{P} \\
\mathrm{d} \\
\mathrm{P}\end{array}$ & $\begin{array}{l}0.218 \\
.021 \\
.032 \\
.036 \\
.184 \\
.113\end{array}$ & $\begin{array}{l}\mathrm{Pd} \\
\mathrm{d} \\
\mathrm{P} \\
\mathrm{P} \\
\mathrm{d} \\
\mathrm{Pd}\end{array}$ \\
\hline
\end{tabular}

1 See table 2 for soil numbers.

2 See table 1 for list of materials and Research Paper No. 359, page 590, for analyses.

${ }^{3} \mathrm{P}=$ pitted; $\mathrm{d}=$ copper-colored discoloration, probably indicating dezincification or redeposition of spongy copper.

Dezincification, which weakens the materials, was evident on most of the alloy specimens. Specimens A, B, and Me, all of which contain approximately 40 percent of zinc, show the highest rates of loss.

\section{LEAD CABLE SHEATH}

Lead is frequently used underground for water services and sometimes lead-sheathed cables are placed in direct contact with the soil, although it is more common practice to draw the cables into ducts. Specimens of two kinds of lead obtained by flattening sections of cable sheath were buried in a considerable number of soils in 1922 and in other soils 2 years later. Table 10 shows the rates of corrosion found for the specimens removed in 1932. It will be noted from table 10 that the rates of loss of weight are considerably lower than for ferrous metals. The rate of penetration is also lower and in most soils it is negligible. In soil no. 1, the specimen of lead containing approximately 1 percent of antimony was punctured in several places as was the corresponding specimen removed in 1930. Since specimens in no other soil have been corroded at nearly the same rate, it appears that the pitting was the result of some peculiarity of the soil rather than of impurities in the metal. Although specimens were not punctured in any soil except soil no. 1, deep pits have been observed in specimens from several sites and it must be concluded that lead is attacked by some soils.

While table 10 and similar data reported in earlier papers apparently indicate somewhat higher rates of corrosion of specimens containing 1 percent of antimony, similar tests conducted on this material and on commercial lead by the Bell Telephone laboratories show no significant difference in the rates of corrosion of the two materials. Some of the Bell Telephone laboratory specimens were buried in the trenches used for the Bureau of Standards tests. Their specimens were much smaller, but more specimens were placed in each location. 
TABLE 10.-Corrosion of lead sheath

\begin{tabular}{|c|c|c|c|c|c|}
\hline $\begin{array}{r}\text { Soil } \\
\text { no. }\end{array}$ & Soil & $\begin{array}{c}\text { Duration } \\
\text { of test } \\
\text { (years) }\end{array}$ & Spec. ${ }^{1}$ & $\begin{array}{l}\text { Loss, oz } \\
\text { per sq ft } \\
\text { per yr. }\end{array}$ & $\begin{array}{l}\text { Pene- } \\
\text { tration } \\
\text { (mils } \\
\text { per yr.) }\end{array}$ \\
\hline 1 & Allis silt loam... & 9.60 & A & 0.203 & 12.4 \\
\hline 3 & Cecil clay loam... & 10.14 & A & .072 & .5 \\
\hline 8 & Fargo clay loam & 9.86 & $\mathrm{~A}$ & .103 & 2.8 \\
\hline 13. & Hanford very fine sandy loam..... & 8.25 & & & \\
\hline 14 & Hempstead silt loam & 9.88 & A & .172 & $\begin{array}{l}3.8 \\
2.9\end{array}$ \\
\hline 16 & Kalmia fine sandy loam. & 10.02 & $\mathrm{~A}$ & .097 & 2.8 \\
\hline 18 & Knox silt loam... & 9. 79 & A & .118 & 3.7 \\
\hline 19 & Lindley silt loam... & 9.71 & $\mathrm{~A}$ & .178 & 2.5 \\
\hline 23 & Merced silt loam... & 10.18 & $\mathrm{~A}$ & (2) .057 & $\begin{array}{ll}1.0 \\
.6\end{array}$ \\
\hline 28 & Montezuma clay adobe. & 7.73 & A & .034 & 4.0 \\
\hline 32 & Ontario loam & 9.57 & $\mathrm{~A}$ & .085 & 1.0 \\
\hline 33 & Peat_-- & 9.66 & $\mathrm{~A}$ & .148 & 1. 9 \\
\hline 37 & St. Johns fine sand & 10.06 & $\mathrm{~A}$ & .100 & 1. 0 \\
\hline 39 & Sassafras silt loam. & 9.88 & A & .103 & 4.1 \\
\hline 40 & Sharkey clay... & 10.04 & $\mathrm{~A}$ & .280 & $\begin{array}{l}0.0 \\
2.8\end{array}$ \\
\hline 42 & Susquehanna clay.-- & 10.07 & A & .061 & $\begin{array}{l}1.8 \\
1.6\end{array}$ \\
\hline 43 & Tidal marsh.- & 9.91 & $\mathrm{~A}$ & .039 & .7 \\
\hline 45 & Unidentified alkali soil_ & 9.85 & $\mathrm{~A}$ & .050 & $\begin{array}{l}1.8 \\
1.5\end{array}$ \\
\hline 46 & Unidentified sandy loam. & 10.15 & H & $\begin{array}{l}.075 \\
.028\end{array}$ & $\begin{array}{l}1.9 \\
2.1\end{array}$ \\
\hline
\end{tabular}

1 A contains approximately 1 percent of antimony; $\mathrm{H}$, commercial lead.

2 Eaten by gophers.

\section{PARIWWY CABLE}

For the transmission of small amounts of power underground, such as the lighting of street lamps, a combination of materials known as "parkway cable" is frequently used. This consists of 1 or more insulated wires surrounded by a lead sheath which is protected by a wraping of fiber impregnated by a bitumen, 2 spiral wrappings of galvanized steel, and an outside wrapping of impregnated fibrous material. Table 11 shows the conditions of the various layers of the specimens removed in 1932 . 
TABLE 11.-Condition of parkway cable

\begin{tabular}{|c|c|c|c|c|c|c|}
\hline Soil number 1 & $\begin{array}{c}\text { Years } \\
\text { buried }\end{array}$ & $\begin{array}{l}\text { Outer } \\
\text { fabric }\end{array}$ & $\begin{array}{l}\text { Inner } \\
\text { fabric }\end{array}$ & $\begin{array}{c}\text { Outer }^{2} \\
\text { steel } \\
\text { wrapper }\end{array}$ & $\begin{array}{l}\text { Inner 2 } \\
\text { steel } \\
\text { wrapper }\end{array}$ & $\begin{array}{l}\text { Lead } \\
\text { sheath }\end{array}$ \\
\hline 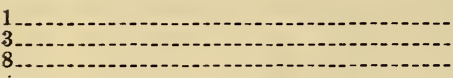 & $\begin{array}{l}9.60 \\
8.13 \\
9.86\end{array}$ & $\begin{array}{l}\mathrm{F}^{3} \\
\mathrm{~B}\end{array}$ & $\begin{array}{l}G \\
G \\
G\end{array}$ & $\begin{array}{l}\mathrm{SR} \\
\stackrel{P}{\mathrm{SR}}\end{array}$ & $\underset{G}{\mathrm{SR}}$ & $\begin{array}{l}W \\
G \\
G\end{array}$ \\
\hline $\begin{array}{l}13 \\
14 \\
16\end{array}$ & $\begin{array}{r}10.18 \\
9.88 \\
8.06\end{array}$ & $\begin{array}{c}\text { BV } \\
\text { B } \\
\text { B }\end{array}$ & $\begin{array}{l}\mathrm{B} \\
\mathrm{G} \\
\mathrm{G}\end{array}$ & $\underset{\mathrm{BR}}{\mathrm{D}}$ & $\begin{array}{l}\text { VBP } \\
\text { SR } \\
\text { G }\end{array}$ & $\begin{array}{c}G \\
G \\
T W\end{array}$ \\
\hline 18 & $\begin{array}{l}979 \\
9.71 \\
9.65\end{array}$ & $\begin{array}{l}\mathrm{F} \\
\mathrm{B} \\
\mathrm{F}\end{array}$ & $\underset{\mathrm{G}}{\mathrm{G}}$ & $\begin{array}{c}\mathrm{G} \\
\mathrm{G} \\
\mathrm{SR}\end{array}$ & $\begin{array}{l}G \\
G \\
G\end{array}$ & $\begin{array}{l}\mathrm{TW} \\
\mathrm{TW}\end{array}$ \\
\hline 328 & $\begin{array}{l}7.73 \\
8.63 \\
9.66\end{array}$ & $\underset{\mathrm{F}}{\mathrm{F}}$ & $\begin{array}{l}G \\
G \\
G\end{array}$ & $\begin{array}{c}\text { BP } \\
\text { GR }\end{array}$ & $\underset{G}{\mathrm{BR}}$ & $\begin{array}{l}\mathrm{G} \\
\mathrm{TW} \\
\mathrm{TW}\end{array}$ \\
\hline 42 & $\begin{array}{l}8.06 \\
8.08 \\
9.91\end{array}$ & $\begin{array}{l}\mathrm{F} \\
\mathrm{F} \\
\mathrm{F}\end{array}$ & $\begin{array}{l}G \\
G \\
G\end{array}$ & $\begin{array}{l}\text { SR } \\
\stackrel{P}{R}\end{array}$ & $\begin{array}{c}\text { SR } \\
\text { SR } \\
\text { G }\end{array}$ & $\underset{\mathbf{T}}{T W}$ \\
\hline $\begin{array}{l}45 \ldots \ldots \\
46 \ldots\end{array}$ & $\begin{array}{r}9.85 \\
10.15\end{array}$ & $\begin{array}{l}F \\
B\end{array}$ & $\stackrel{G}{G}$ & $\underset{\mathrm{BR}}{\mathrm{R}}$ & $\begin{array}{l}\text { SR } \\
\text { SR }\end{array}$ & $\underset{T W}{\text { T }}$ \\
\hline
\end{tabular}

1 See table 2 for names of soils.

2 All steel galvanized.

3 Ratings: G, good; F, fair; B, bad; R, rusted; SR, slightly rusted; BR, badly rusted, TW, thin white corrosion product on lead sheath; W, white corrosion product on lead sheath; V, very; P, pitted; D destroyed. (Ratings by E. R. Shepard and I. A. Denison.)

\section{MISCELLANEOUS METALS AND ALLOYS}

About the time the Bureau of Standards started its study of soil corrosion, the United States Bureau of Mines started an investigation of metals suitable for use in mines. The Bureau of Standards was asked by the Bureau of Mines to bury certain specimens it had collected; and later, to avoid duplication of work, the Bureau of Standards undertook to report the results of its tests of these materials.

TABLE 12.-Corrosion of miscellaneous metals and alloys

[A verage of 2 specimens]

\begin{tabular}{|c|c|c|c|c|c|c|c|c|c|c|}
\hline \multirow{5}{*}{ Material 2} & \multicolumn{10}{|c|}{ Soil number ${ }^{1}$} \\
\hline & \multicolumn{2}{|c|}{13} & \multicolumn{2}{|c|}{29} & \multicolumn{2}{|c|}{42} & \multicolumn{2}{|c|}{43} & \multicolumn{2}{|c|}{45} \\
\hline & \multicolumn{10}{|c|}{ Duration of test (years) } \\
\hline & \multicolumn{2}{|c|}{8.25} & \multicolumn{2}{|c|}{8.10} & \multicolumn{2}{|c|}{8.08} & \multicolumn{2}{|c|}{8.63} & \multicolumn{2}{|c|}{8.70} \\
\hline & Loss ${ }^{3}$ & Pits 4 & Loss & Pits & Loss & Pits & Loss & Pits & Loss & Pits \\
\hline $\begin{array}{l}\text { A... } \\
\text { B }-. \\
\text { C1 } \\
\text { C2 } \\
\text { C3..- }\end{array}$ & $\begin{array}{r}0.767 \\
.050 \\
.013 \\
.022\end{array}$ & $\begin{array}{l}6.42 \\
0 \\
1.70 \\
(7)\end{array}$ & $\begin{array}{r}0.757 \\
.232 \\
.111 \\
.096\end{array}$ & $\begin{array}{l}7.28 \\
0 \\
(5) \\
(5) \\
(5)\end{array}$ & $\begin{array}{r}0.380 \\
.011 \\
.010 \\
.008 \\
6.129\end{array}$ & $\begin{array}{l}4.45 \\
0 \\
0 \\
1.60 \\
(5)\end{array}$ & $\begin{array}{r}2.008 \\
.015 \\
.001 \\
.001 \\
.004\end{array}$ & $\begin{array}{l}(5) \\
0 \\
0 \\
0 \\
0\end{array}$ & $\begin{array}{r}61.453 \\
.097 \\
6.033 \\
.034 \\
6.145\end{array}$ & $\begin{array}{l}(5) \\
0 \\
(7) \\
3.56 \\
(5)\end{array}$ \\
\hline $\begin{array}{l}\mathrm{H} \\
\mathrm{L} \\
\mathrm{L} \\
\mathrm{N} \\
\mathrm{N} \bar{N}_{-. .}\end{array}$ & $\begin{array}{l}.008 \\
.023 \\
.118 \\
.040\end{array}$ & $\begin{array}{l}0 \\
0 \\
0 \\
0\end{array}$ & $\begin{array}{l}.144 \\
.159 \\
.512 \\
.314\end{array}$ & $\begin{array}{l}.99 \\
0 \\
0 \\
0\end{array}$ & $\begin{array}{l}.017 \\
.026 \\
.118 \\
.084\end{array}$ & $\begin{array}{l}0 \\
0 \\
0 \\
0\end{array}$ & $\begin{array}{l}.510 \\
.471 \\
.076 \\
.049\end{array}$ & $\begin{array}{l}1.62 \\
0 \\
0 \\
0\end{array}$ & $\begin{array}{r}.024 \\
6.028 \\
6.098 \\
6.043\end{array}$ & $\begin{array}{l}0^{.92} \\
0 \\
0\end{array}$ \\
\hline 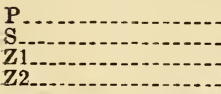 & $\begin{array}{l}.919 \\
.333 \\
.283\end{array}$ & $\begin{array}{l}(5) \\
5.94 \\
6.55\end{array}$ & $\begin{array}{r}.506 \\
.763 \\
.536 \\
.549\end{array}$ & $\begin{array}{l}3.70 \\
(7) \\
3.33 \\
4.93\end{array}$ & $\begin{array}{l}.476 \\
.056 \\
.063\end{array}$ & $\begin{array}{l}\text { (7) } \\
.62 \\
1.14\end{array}$ & $\begin{array}{r}1.295 \\
.176 \\
.242\end{array}$ & $\begin{array}{l}(7) \\
(7) \\
8.11\end{array}$ & $\begin{array}{r}6.302 \\
61.576 \\
6.995 \\
{ }^{3} 1.027\end{array}$ & $\begin{array}{l}(7) \\
(5) \\
(7) \\
12.8\end{array}$ \\
\hline
\end{tabular}

1 See table 2 for names of soils.

2 See table 1 for names of materials.

3 Loss in ounces per square foot per year.

4 A verage of deepest pit on each of 2 specimens in mils per year.

Spacimen partly destroyed.

One specimen only.

7 Holes through one or both specimens. 
Table 12 gives the corrosion data on such Bureau of Mines specimens as were removed in 1932. These specimens are described briefly in table 1. As the specimens differed in thickness, comparison of specimens that were punctured is somewhat difficult. The condition of the aluminum specimens $\mathrm{C} 1, \mathrm{C} 2, \mathrm{C} 3$ was similar to that of those removed in the earlier periods and indicated the superiority of commercially pure aluminum and aluminum-manganese alloy such as material C2 over the duralumin type of alloys and the unsuitability of the latter for exposure to such conditions without adequate protective measures. There seems to be no significant difference in the behavior of the two varieties of lead N and NN. Although so far as is known to the Bureau of Standards, the two specimens Z1 and Z2 differ only in thickness, the thinner specimen $\mathrm{Z} 1$ corroded less in all soils in which the specimens were buried.

\section{CORROSION OF METALLIC PROTECTIVE COATINGS}

\section{GALVANIZED PIPE AND SHEET}

A study of galvanized materials was started in 1924. It was hoped that several questions would be answered by the investigation. The major question, of course, was the action of soils on zinc and zinc iron-alloy. In addition, it was hoped that data could be obtained on the proper weight of zinc coating for different soil conditions. Information was also desired as to whether the nature of the ferrous metal beneath the zinc influenced the rate of corrosion. Perhaps the experiment would have been modified somewhat if the unavoidably wide spread of underground corrosion data had been realized or if the claims of the proponents of some of the galvanized materials had been more modest and less conflicting.

The precision of the data on the performance of galvanized materials underground is influenced not only by the variability of soil conditions, but by the difficulty of applying an exact amount of zinc and the still greater difficulty of distributing that zinc uniformly over the surface of the metal to be coated. If a large sheet of galvanized material is subdivided into sections of the size used in the experiment, a considerable variation in the weight of coating on the several sections may be expected. Consequently the failure of one kind of galvanized material prior to the failure of another kind carrying nominally the same weight of zinc may be due to differences in the actual weights of the coatings rather than to the differences in the base materials. The uncertainties on this account can only be overcome by using a large number of specimens and neglecting small apparent differences.

Table 13 gives the data on the pipe and sheet buried in all soils. The nominal weight of all coatings was 2 ounces per square foot, but the actual weight of the coatings departed considerably from this value. It will be seen that the rates of loss of weight and penetration are considerably less than the corresponding losses of the ferrous specimens, which indicates that zinc is more resistant to soil action than iron. 
TABLE 13.-Corrosion of galvanized pipe and 16-gage sheet

\begin{tabular}{|c|c|c|c|c|c|c|c|c|c|c|c|c|c|}
\hline \multirow{2}{*}{ Soil number ${ }^{1}$} & \multirow{2}{*}{$\begin{array}{c}\text { Dura- } \\
\text { tion of } \\
\text { test } \\
\text { (years) }\end{array}$} & \multicolumn{4}{|c|}{$\begin{array}{l}\text { Rate of loss of weight in ounces } \\
\text { per square foot per year }\end{array}$} & \multicolumn{4}{|c|}{$\begin{array}{l}\text { Rates of penetration } \\
\text { in mils per year }{ }^{6}\end{array}$} & \multicolumn{4}{|c|}{ Condition ? } \\
\hline & & $\underset{(\text { pipe })^{2}}{A}$ & $\mathrm{~A} 3{ }^{3}$ & $\mathrm{~B}^{4}$ & Y 35 & A & A3 & B & Y3 & A & A3 & B & Y3 \\
\hline & $\begin{array}{l}8.62 \\
8.13 \\
8.73 \\
8.66 \\
8.25\end{array}$ & $\begin{array}{l}0.332 \\
.038 \\
.057 \\
.048 \\
.140\end{array}$ & $\begin{array}{l}0.350 \\
.035 \\
.033 \\
.029 \\
.207\end{array}$ & $\begin{array}{l}0.396 \\
.034 \\
.032 \\
.051 \\
.080\end{array}$ & $\begin{array}{l}0.403 \\
.030 \\
.035 \\
.047 \\
.238\end{array}$ & & \begin{tabular}{r}
1.28 \\
.74 \\
\hdashline 2.42 \\
1.82
\end{tabular} & \begin{tabular}{r}
1.97 \\
.62 \\
\hdashline 2.89 \\
.61
\end{tabular} & \begin{tabular}{r}
2.09 \\
.62 \\
\hdashline 3.23 \\
1.82
\end{tabular} & $\begin{array}{l}\mathrm{U} \\
\mathrm{E} \\
\mathrm{E} \\
\mathrm{R} \\
\mathrm{E}\end{array}$ & $\begin{array}{l}\mathrm{P} \\
\mathrm{R} \\
\mathrm{E} \\
\mathrm{P} \\
\mathrm{P}\end{array}$ & $\begin{array}{l}\mathrm{U} \\
\mathrm{R} \\
\mathrm{E} \\
\mathrm{P} \\
\mathrm{R}\end{array}$ & $\begin{array}{l}\mathrm{U} \\
\mathrm{E} \\
\mathrm{E} \\
\mathrm{P} \\
\mathrm{U}\end{array}$ \\
\hline $\begin{array}{ll}19- \\
20\end{array}$ & $\begin{array}{l}8.76 \\
8.06 \\
8.60 \\
8.59 \\
8.62\end{array}$ & $\begin{array}{l}.028 \\
.333 \\
.029 \\
.069 \\
.141\end{array}$ & $\begin{array}{l}.014 \\
.106 \\
.016 \\
.028 \\
.146\end{array}$ & $\begin{array}{l}.014 \\
.161 \\
.015 \\
.010 \\
.305\end{array}$ & $\begin{array}{l}.015 \\
.095 \\
.021 \\
.034 \\
.104\end{array}$ & & $\begin{array}{c}1.61 \\
1.97\end{array}$ & \begin{tabular}{l}
1.74 \\
\hdashline 1.05 \\
2.78
\end{tabular} & $\begin{array}{c}1.61 \\
.81\end{array}$ & $\begin{array}{l}\mathbf{E} \\
\mathbf{E} \\
\mathbf{E} \\
\mathbf{E} \\
\mathrm{R}\end{array}$ & $\begin{array}{l}\mathbf{E} \\
\mathrm{U} \\
\mathbf{E} \\
\mathbf{E} \\
\mathbf{P}\end{array}$ & $\begin{array}{l}\mathbf{E} \\
\mathrm{P} \\
\mathbf{E} \\
\mathrm{R} \\
\mathbf{P}\end{array}$ & $\begin{array}{l}\mathrm{E} \\
\mathrm{P} \\
\mathrm{E} \\
\mathrm{R} \\
\mathrm{U}\end{array}$ \\
\hline $\begin{array}{l}29- \\
32 \\
-\end{array}$ & $\begin{array}{l}7.97 \\
8.25 \\
7.73 \\
8.10 \\
8.63\end{array}$ & $\begin{array}{l}.098 \\
9.945 \\
8.177 \\
8.484 \\
.037\end{array}$ & $\begin{array}{l}.358 \\
.463 \\
.286 \\
.026\end{array}$ & $\begin{array}{l}.260 \\
.082 \\
.554 \\
.020\end{array}$ & $\begin{array}{l}.628 \\
.066 \\
.390 \\
.022\end{array}$ & 1.98 & $\begin{array}{l}3.58 \\
5.95 \\
4.94\end{array}$ & $\begin{array}{r}2.12 \\
.91 \\
3.21\end{array}$ & $\begin{array}{r}4.00 \\
.65 \\
4.70 \\
\end{array}$ & $\begin{array}{l}\mathrm{R} \\
\mathrm{P} \\
\mathrm{E} \\
\mathrm{P} \\
\mathrm{E}\end{array}$ & $\begin{array}{l}\mathrm{P} \\
\mathrm{P} \\
\mathrm{P} \\
\mathrm{E}\end{array}$ & $\begin{array}{l}\mathrm{P} \\
\mathrm{U} \\
\mathrm{P} \\
\mathrm{E}\end{array}$ & $\begin{array}{l}\mathrm{P} \\
\mathrm{R} \\
\mathrm{P} \\
\mathrm{E}\end{array}$ \\
\hline 40 & $\begin{array}{l}8.63 \\
8.06 \\
8.51 \\
8.09 \\
8.08\end{array}$ & $\begin{array}{r}.171 \\
.233 \\
.073 \\
8.036\end{array}$ & $\begin{array}{l}.171 \\
.338 \\
.113 \\
.028\end{array}$ & $\begin{array}{c}.213 \\
.396 \\
.156 \\
.027\end{array}$ & $\begin{array}{c}.182 \\
.107 \\
.029\end{array}$ & & $\begin{array}{l}1.85 \\
2.61 \\
2.35\end{array}$ & $\begin{array}{l}1.97 \\
2.23 \\
1.88 \\
-\ldots . \\
\end{array}$ & $\begin{array}{l}1.62 \\
2.00\end{array}$ & \begin{tabular}{c}
$\mathrm{U}$ \\
$\mathrm{R}$ \\
\hdashline $\mathrm{E}$ \\
$\mathrm{E}$
\end{tabular} & $\begin{array}{l}\mathrm{P} \\
\mathrm{P} \\
\mathrm{P} \\
\mathrm{E}\end{array}$ & $\begin{array}{l}\mathrm{P} \\
\mathrm{P} \\
\mathrm{P} \\
\mathrm{R}\end{array}$ & $\begin{array}{l}P \\
P \\
P \\
-E\end{array}$ \\
\hline $\begin{array}{l}43 . \\
45- \\
46-\end{array}$ & $\begin{array}{l}8.63 \\
8.70 \\
8.69\end{array}$ & $\begin{array}{r}8.114 \\
8284 \\
.048\end{array}$ & $\begin{array}{l}.068 \\
.057 \\
.008\end{array}$ & $\begin{array}{l}.155 \\
.302 \\
.005\end{array}$ & $\begin{array}{l}.100 \\
.078 \\
.007\end{array}$ & & $\begin{array}{r}.81 \\
1.03\end{array}$ & $\begin{array}{l}3.82 \\
4.95\end{array}$ & $\begin{array}{l}.58 \\
.69\end{array}$ & $\begin{array}{l}\mathrm{E} \\
\mathrm{U} \\
\mathrm{E}\end{array}$ & $\begin{array}{l}\mathrm{U} \\
\mathrm{U} \\
\mathrm{E}\end{array}$ & $\begin{array}{l}\mathrm{P} \\
\mathrm{P} \\
\mathrm{E}\end{array}$ & $\begin{array}{l}\mathrm{U} \\
\mathrm{U} \\
\mathrm{E}\end{array}$ \\
\hline
\end{tabular}

1 See table 2 for names of soils.

$2 \mathrm{~A}=$ pure open-hearth iron pipe. Coating $=282$ ounces per square foot.

3 A $3=$ pure open-hearth iron sheet. Coating $=198$ ounces per square foot.

B $=$ Bessemer steel sheet. Coating $=162$ ounces per square foot.

$6 \mathrm{Y} 3=$ Open-hearth steel sheet, 0.2 percent copper. Coating $=2.15$ ounces per square foot.

6 Maximum penetration obtained by averaging deepest pit on each side of sheet.

7 Symbols: $U=$ uniformly corroded.

$$
\begin{aligned}
& \mathrm{E}=\text { excellent. } \\
& \mathrm{R}=\text { rusted. } \\
& \mathrm{P}=\text { pitted. }
\end{aligned}
$$

8 A verage of 2 specimens.

${ }^{\theta}$ A verage of 3 specimens.

Although the 3 varieties of base materials were selected in order to determine whether one was preferable to another for galvanizing purposes, the table answers the question only in a negative way. So far as can be determined from the data there is no significant difference in the corrosion resisting properties of the three kinds of specimens. Such differences as are apparent can be accounted for by variations in soil conditions or in the weight of the coatings. If table 13 is compared with the corresponding data for the 6 -year period as shown in table 11 of Research Paper 359, it will be found that there is little definite evidence of an increased rate of corrosion of the older specimens. This indicates that the corrosion is still controlled by the zinc coating, although in many test localities this coating has been punctured. The letters in the last 4 columns of table 13 indicate the condition of the specimens. These columns are perhaps the most valuable part of the table, since no satisfactory way has been found to remove rust from the plates without removing zinc also and deviations of the surface of the plates from perfect planes made accurate pit measurements impossible. 


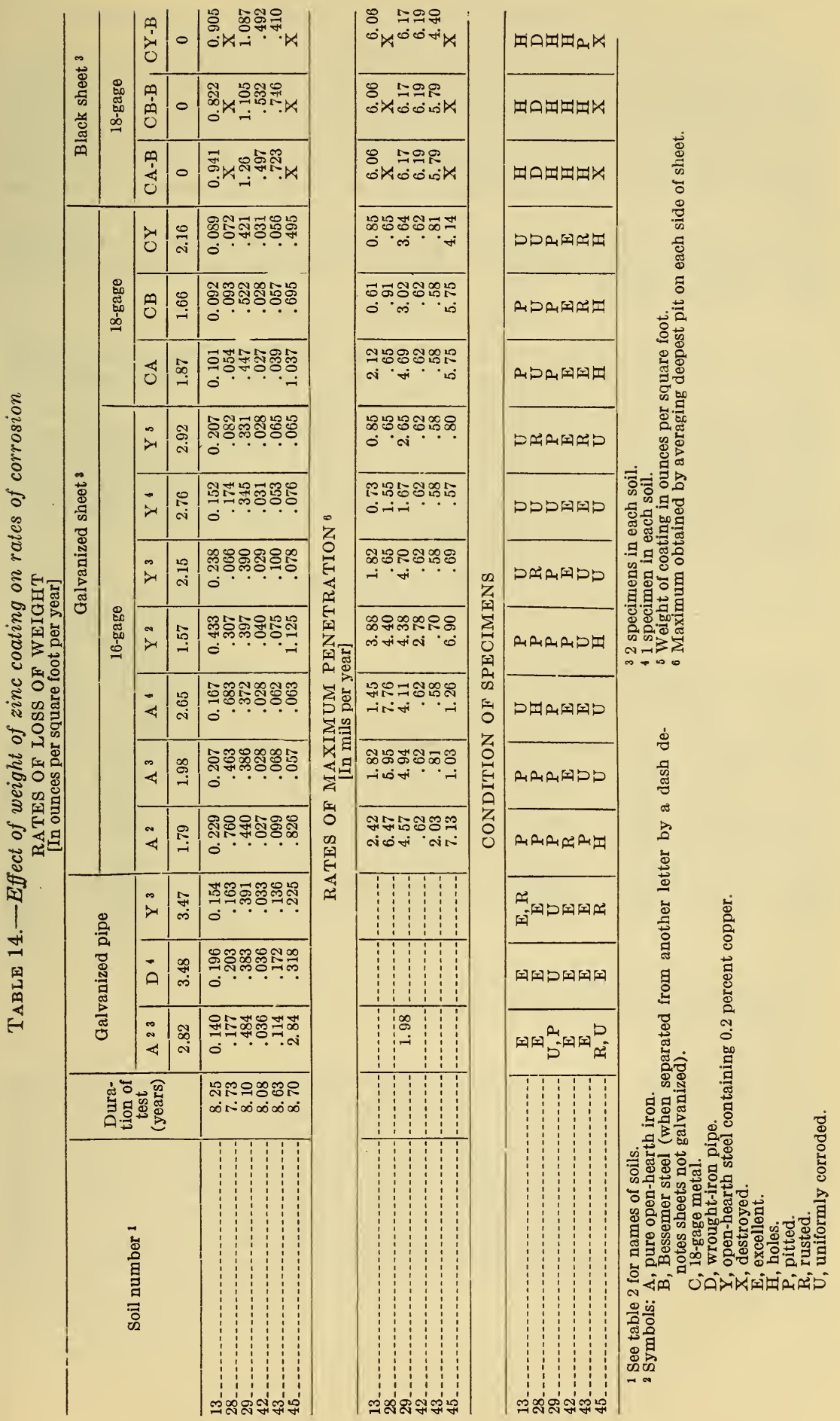




\section{RELATION OF WEIGHT OF ZINC COATING TO CORROSION}

In addition to the galvanized pipe and sheet described above, specimens of pipe and sheet having other weights of coating were removed from six soils and the results of their examinations are given in table 14 , in which are repeated some of the data of table 13 . It will be seen that, in general, the specimens carrying the heaviest coatings resisted soil action best, but there are a number of exceptions to this rule.

In the last three columns are given data on specimens of materials which were not galvanized in order that the effects of the zinc may be seen more readily.

\section{LEAD-COATED PIPE}

Since lead corrodes more slowly than iron under most soil conditions, it was thought that lead-coated pipe might be satisfactory for underground use. Specimens of lead-coated pipe were buried at some test sites in 1922 and at others in 1924. Data on specimens of this kind removed in 1932 are given in table 15. The thickness of the coating is about 0.002 of an inch and as might be anticipated from a study of the data on the lead cable sheaths, the coating was punctured in a large number of the soils.

TABLE 15.-Corrosion of lead-coated steel pipe

\begin{tabular}{|c|c|c|c|c|c|c|c|}
\hline Soil number 1 & $\begin{array}{c}\text { Duration } \\
\text { of test } \\
\text { (years) }\end{array}$ & $\begin{array}{c}\text { Rate of loss } \\
\text { of weight } \\
\text { in ounces } \\
\text { per square } \\
\text { foot per } \\
\text { year } 2\end{array}$ & $\begin{array}{c}\text { Rates of } \\
\text { maximum } \\
\text { penetra- } \\
\text { tion in mils } \\
\text { per year }{ }^{2}\end{array}$ & Soil number ${ }^{1}$ & $\begin{array}{c}\text { Duration } \\
\text { of test } \\
\text { (years) }\end{array}$ & $\begin{array}{c}\text { Rate of loss } \\
\text { of weight } \\
\text { in ounces } \\
\text { per square } \\
\text { foot per } \\
\text { year } 2\end{array}$ & $\begin{array}{c}\text { Rates of } \\
\text { maximum } \\
\text { penetra- } \\
\text { tion in mils } \\
\text { per year }{ }^{2}\end{array}$ \\
\hline 113 & \begin{tabular}{l|}
8.62 \\
8.13 \\
8.73 \\
8.66 \\
8.25
\end{tabular} & $\begin{array}{l}0.438 \\
.075 \\
.073 \\
.097 \\
.051\end{array}$ & $\begin{array}{r}10.4 \\
5.9 \\
9.4 \\
4.4 \\
5.3\end{array}$ & $\begin{array}{l}28 \ldots \ldots \\
29 \\
32 \\
33 . \ldots . \\
37 \ldots \ldots\end{array}$ & $\begin{array}{l}7.73 \\
8.10 \\
8.63 \\
8.63 \\
8.06\end{array}$ & $\begin{array}{r}0.126 \\
.640 \\
.074 \\
.475 \\
.240\end{array}$ & $\begin{array}{r}8.7 \\
7.0 \\
5.6 \\
7.0 \\
6.5\end{array}$ \\
\hline $\begin{array}{l}14 \\
16 \\
18 \\
20 \\
23\end{array}$ & $\begin{array}{l}8.76 \\
8.06 \\
8.60 \\
8.62 \\
8.25\end{array}$ & $\begin{array}{r}.029 \\
.172 \\
.036 \\
.230 \\
.149\end{array}$ & $\begin{array}{r}4.3 \\
6.1 \\
7.0 \\
6.3 \\
310.1\end{array}$ & 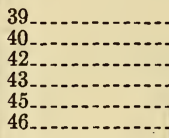 & $\begin{array}{l}8.51 \\
8.09 \\
8.08 \\
8.63 \\
8.70 \\
8.69\end{array}$ & $\begin{array}{l}.087 \\
.134 \\
.063 \\
.238 \\
.195 \\
.036\end{array}$ & $\begin{array}{r}7.3 \\
6.5 \\
2.8 \\
10.3 \\
8.5 \\
3.4\end{array}$ \\
\hline
\end{tabular}

1 See table 2 for names of soils.

2 A verage of 2 specimens except as otherwise noted.

3 A verage of 4 specimens.

4 specimen only.

If the depths of pits on the lead-coated specimens are compared with the depths of the pits on uncoated steel pipe in the same soils for the same periods of exposure, it will be found that in some soils the pitting on the coated specimens is the deeper and in other soils the shallower. The differences in the rate of pitting between the coated and bare pipe are not great and may be attributed to accidental conditions. There is little definite evidence indicating that the pitting was accelerated by the difference of potential between iron and lead. 
TABLE 16.-Corrosion of calorized specimens

\begin{tabular}{|c|c|c|c|c|c|}
\hline \multirow{2}{*}{ Soil number 1} & \multirow{2}{*}{$\begin{array}{l}\text { Duration } \\
\text { of test } \\
\text { (years) }\end{array}$} & \multicolumn{2}{|c|}{$\begin{array}{l}\text { Rates }{ }^{2} \text { of loss of weight } \\
\text { in ounces per square } \\
\text { foot per year }\end{array}$} & \multicolumn{2}{|c|}{$\begin{array}{l}\text { Rates }^{2} \text { of maximum } \\
\text { penetration in mils } \\
\text { per year }\end{array}$} \\
\hline & & $\begin{array}{l}\text { Dry cal- } \\
\text { orized }\end{array}$ & $\begin{array}{l}\text { Wet cal- } \\
\text { orized }\end{array}$ & $\begin{array}{l}\text { Dry cal- } \\
\text { orized }\end{array}$ & $\begin{array}{l}\text { Wet cal- } \\
\text { orized }\end{array}$ \\
\hline & $\begin{array}{l}8.25 \\
7.73 \\
8.10 \\
8.08 \\
8.63 \\
8.70\end{array}$ & $\begin{array}{r}0.214 \\
.310 \\
.376 \\
.174 \\
.800 \\
.496\end{array}$ & $\begin{array}{c}0.082 \\
.335 \\
.077 \\
.820 \\
.260\end{array}$ & $\begin{array}{l}3.36 \\
5.66 \\
4.50 \\
5.07 \\
3.22 \\
5.69\end{array}$ & $\begin{array}{c}4.33 \\
-7.01 \\
6.32 \\
4.22 \\
5.17\end{array}$ \\
\hline
\end{tabular}

1 See table 2 for names of oils.

2 A verage of 2 specimens.

\section{CALORIZED PIPE}

Specimens of calorized steel pipe prepared by two processes were buried in seven soils in 1924. Table 16 gives the results of the examination of the calorized specimens removed in 1932. The data indicate that the treatment of the specimens reduced the rates of corrosion materially but did not afford complete protection against soil action. It should be noted that all of the soils from which calorized specimens were removed are above the average in corrosiveness with respect to ferrous materials.

\section{SHERARDIZED AND LEAD-COATED BOLTS}

At the request of the corrosion committee of the American Foundrymen's Association, which was interested in bolts for pipe flanges and fittings used underground, specimens of sherardized, lead-coated, and wrought-iron bolts and nuts were buried in six corrosive soils.

Table 17 shows the rates of loss of weight of the specimens removed in 1932. Both treatments of the bolts increased their resistance to corrosion. It is doubtful whether the differences between the rates of loss of weight for the sherardized and lead-coated bolts are significant.

TABLE 17.-Rates of loss of weight of bolts and nuts

[A verage of 4 specimens in ounces per square foot per year]

\begin{tabular}{|c|c|c|c|c|c|c|c|}
\hline \multirow{2}{*}{ Soil number ${ }^{1}$} & \multirow{2}{*}{$\begin{array}{c}\text { Duration } \\
\text { of test } \\
\text { (years) }\end{array}$} & \multicolumn{3}{|c|}{ Bolts } & \multicolumn{3}{|c|}{ Nuts } \\
\hline & & $G^{2}$ & $\mathrm{D}$ & $\mathrm{F}$ & $G$ & $\mathrm{D}$ & F \\
\hline 429 & $\begin{array}{l}8.25 \\
7.73 \\
8.10 \\
8.08 \\
8.63 \\
8.70\end{array}$ & $\begin{array}{l}0.247 \\
.604 \\
.647 \\
.193 \\
.922 \\
.615\end{array}$ & $\begin{array}{l}1.252 \\
2.901 \\
1.132 \\
.592 \\
1.564 \\
1.479\end{array}$ & $\begin{array}{l}0.267 \\
.881 \\
.194 \\
.499 \\
.526\end{array}$ & $\begin{array}{l}0.255 \\
.755 \\
.361 \\
.171 \\
.528 \\
.400\end{array}$ & $\begin{array}{r}1.132 \\
2.573 \\
1.242 \\
.402 \\
.925 \\
1.724\end{array}$ & $\begin{array}{l}0.251 \\
.752 \\
.188 \\
.409 \\
.433\end{array}$ \\
\hline
\end{tabular}

1 See table 2 for names of soils.

$2 \mathrm{D}=$ wrought iron; $\mathrm{F}=$ lead-coated; $\mathrm{G}=$ sherardized.

One specimen only.

$23797-33-10$ 


\section{CONCLUSION}

The data presented in this report are for the more corrosive soils in the investigation and do not represent the average corrosiveness of all soils.

The data are in substantial agreement with those presented in earlier reports and support the conclusions already reached.

There are indications that the rate of corrosion decreases with time in most soils because of more stable trench conditions or the formation of corrosion products. The rate of decrease in general diminishes with time, indicating that a fixed rate of corrosion may ultimately be reached.

On account of unavoidable variations in soils of the same type, in metals even of the same kind, and in methods of construction, exact rates of corrosion cannot bo predicted, but approximate rates of corrosion can be given for specified metals and soil conditions.

Differences in the rate of penetration of different pipe-line materials by soil action in the same soil are much smaller than differences in the rate of penetration of the same material in different soils. The type of soil rather than the variety of ferrous material is usually the controlling factor with respect to corrosion. In certain soils, however, one type of material may corrode much more rapidly than some other material and for this reason the soil to which it is to be exposed should be considered in selecting material for a pipe line.

The maximum rate of corrosion on a pipe line may be greater than the rate given in this report for the same material and soil because of the greater exposed area and local adverse conditions. Lower rates of corrosion over the same period of exposure are not to be expected.

Additional correlations between rates of corrosion and soil types should make the soil survey maps and reports of the United States Department of Agriculture of great value in preliminary estimations of soil corrosivity in territories where new lines are to be laid.

Copper, and alloys high in copper, corrode less rapidly than most ferrous materials in the soils investigated.

A zinc coating weighing 1 ounce per square foot of exposed surface should extend the life of the coated material at least 6 years in very corrosive soils and much longer under more favorable conditions.

This report is the joint product of nearly all of the members of the underground corrosion section of the Bureau. R. H. Taylor and Robert B. Hobbs are responsible for the supervision of the cleaning of the specimens and the determination of losses of weight and pit depths. All of the calculations were made or checked by $\mathrm{i}$. R. Shepard. Both he and I. A. Denison have taken an active part in determining the significance of the data, as have those mentioned earlier, though to a less extent. Suggestions have also been received from other members of the section and from cooperating manufacturers and public-utility associations. 


\section{APPENDIX 1. ERRATA IN EARLIER PUBLICATIONS}

Although each step in the determination of the data has been taken independently by two persons and considerable care has been exercised in the transfer of data from one stage of production to the next, errors have crept into all of the reports on the underground-corrosion investigation. None of the errors so far discovered affect the general conclusions which have been reached and most of them are within the limits of the errors of the experiments. There are a few, however, which interfere somewhat with the comparison of data from year to year or with the comparison of materials in certain soils.

Below are tabulated all the errors so far discovered in the earlier publications on underground corrosion which appear to be of any importance.

Notices of errors or omissions in the present report or in the earlier ones will be appreciated.

Technologic Paper No. 368. Co."

Page 451, change "Nugent Steel Castings Co." to read "Sivier Steel Castings

Page 454, under E, Muntz metal, change " $3 / 4$ inch" to read " $1 / 2$-inch I.P.S." Page 454, under F, Copper steel tube, change "15 percent" to read "1.5 percent.

Page 530, under list of organizations include "The Barrett Co.-C. S. Reeve." Research Paper No. 329.

Page 12, table 7 , under copper bearing steel, soil 29 , change " 2.01 " to read "1.98."

Page 13, table 8, under pure open-hearth iron, soil 23, change " 27 " to read " 18 "; under sand mold cast iron, soil 23 , change " 51 " to read " 35 ".

Page 21, table 16, under a, Soil 23, change " 27 " to read " 23.6 "; tables 17 and 18 , footnote 1 , change "table 8" to read "table 5"; tables 11 to 16 , footnote 1. Change "table 4 " to read "table 5."

Page 23, table 18, under a, soil 23 , change " 2.4 " to read " 24 ," for soil 40 , make the following changes: under $\mathrm{B}$, " 11.1 " to read " 8.2 "; $\mathrm{K}$, " 14.9 " to read "11.9"; M, "14.4" to read " 11.5 "; Y, " 13.3 " to read " 10.3 "; L, " 12.7 " to read " $8.2 " ; Z$, " 13.6 " to read " 9.7 ".

Page 25, table 20, under a, soil 23, change "23.6" to read "25".

Page 26, table 21, under rates of Penetration for 8 years, soil 23, change " 21.7 " to read " 20.7 ".

Page 33, table 23 , under I, soil 45 , change " 1.137 " to read " 1.297 ".

Page 34, table 25, under Age of Specimens, soil 120, change "1.95" to read " 1.97 ", and for soil 121 , change " 1.97 " to read " 1.95 ".

Research Paper No. 359.

Page 593, table 7, under Description, for D, F, and G, change " 2 " to read " 3.5 " after bolts.

Page 598, table 11, for soil 1, under A3, change "7.993" to read " 0.7993 "; under B change " 6.627 " to read " 0.6627 "; under Y3 change "6.769" to read " 0.6769 ".

Page 604, table 17, in footnote change " $\mathrm{D}$ " to read " $\mathrm{K}$ ", " $\mathrm{K}$ " to read " $\mathrm{D}$ ", " $M$ " to read " $\mathrm{P}$ ", "P" to read " $\mathrm{M}$ ".

Washington, August 9, 1933. 